BIS WORKING PAPERS

No 91 - October 2000

\title{
MEASURING POTENTIAL VULNERABILITIES IN EMERGING MARKET ECONOMIES
}

by

John Hawkins and Marc Klau

BANK FOR INTERNATIONAL SETTLEMENTS

Monetary and Economic Department

Basel, Switzerland 
BIS Working Papers are written by members of the Monetary and Economic Department of the Bank for International Settlements, and from time to time by other economists, and are published by the Bank. The papers are on subjects of topical interest and are technical in character. The views expressed in them are those of their authors and not necessarily the views of the BIS.

Copies of publications are available from:

Bank for International Settlements

Information, Press \& Library Services

CH-4002 Basel, Switzerland

Fax: $+4161 / 2809100$ and $+4161 / 2808100$

This publication is available on the BIS website (www.bis.org).

(C) Bank for International Settlements 2000.

All rights reserved. Brief excerpts may be reproduced or translated provided the source is stated. 
BIS WORKING PAPERS

No 91 - October 2000

\title{
MEASURING POTENTIAL VULNERABILITIES IN EMERGING MARKET ECONOMIES
}

\author{
by
}

John Hawkins and Marc Klau*

\begin{abstract}
This paper describes some experiments with the construction of relatively simple indices which summarise in a systematic and objective way information about emerging economies currently under pressure in financial markets and those vulnerable to such pressure in the future. A survey of the literature suggests financial crises are typically preceded by overvalued exchange rates, inadequate international reserves, recessions and excessive credit growth. These indicators and others, such as short-term external debt, which appear more important in recent crises are included in the summary indices of vulnerability. The vulnerability indices are shown to have modest predictive power for the pressure index but are far from conclusive in themselves.
\end{abstract}

* The authors wish to thank Ib Madsen, who was heavily involved in the early stages of the project and commented on this paper, and Philip Turner, who has overseen it throughout. Expert secretarial assistance by Gabriela Salvisberg is gratefully acknowledged. Helpful comments were also received from Palle Andersen, Stephan Arthur, Claudio Borio, Nigel Hulbert, Dubravko Mihaljek, Setsuya Sato, Bill White and colleagues in central banks. 



\section{Contents}

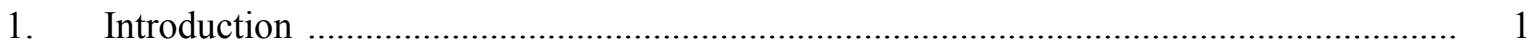

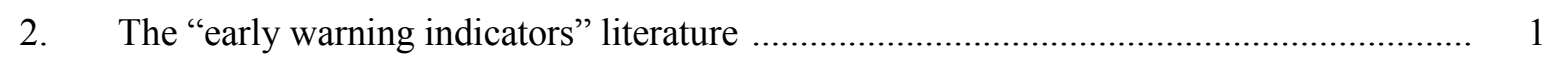

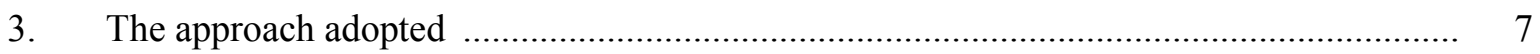

4. Further issues concerning indicators, economies and weights used ................................ 9

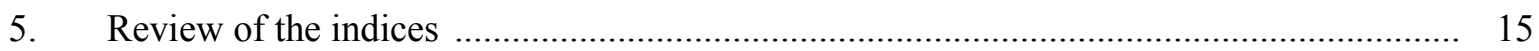

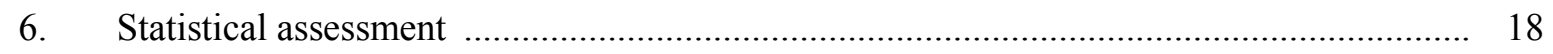

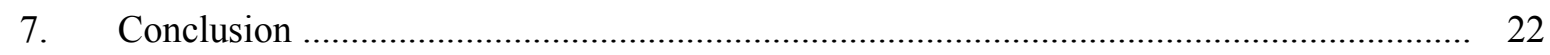

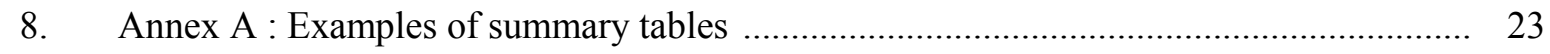

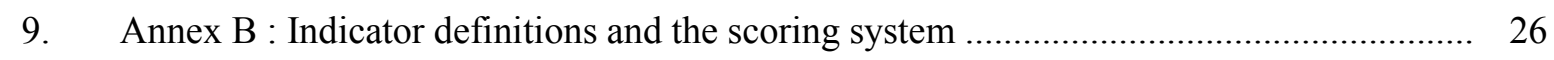

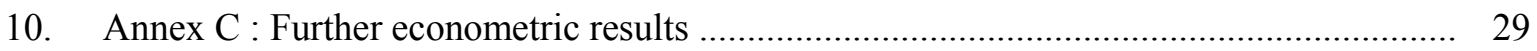

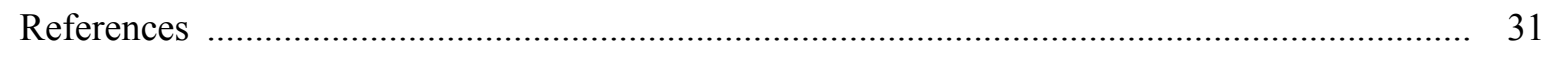





\section{Introduction}

The global economy was shaken by a series of financial crises in the late 1990s. While the epicentres of these shocks were in Mexico, east Asia, Russia and Brazil respectively, they were felt more globally. One financial "tsunami" swept across the Pacific from Mexico in 1995 affecting Asian (and other) financial markets, and another travelled in the opposite direction in 1997. In September 1998 the Russian financial crisis caused a worldwide retreat from risk and reduced liquidity globally. Brazil also caused tremors, but these were largely confined to neighbouring countries.

These events led to extensive research into what variables, if any, can serve best as measures of the pressure various emerging economies currently face and those making them vulnerable to pressure in the future. ${ }^{1}$ This is an evolving process and this paper should mainly be interpreted as presenting preliminary results as a contribution to this debate.

The burgeoning literature on "early warning indicators", which has helped inform the choice of indicators in the experimental framework, is surveyed in Section 2. The principles underlying the use of statistical indicators for the monitoring of developments in emerging market economies are described in Section 3. This involved the "scoring" of certain indicators to produce aggregate indices. Section 4 and Annex B give further details of the indicators used, economies covered and calculations of the indices. The sample period involved is too short to employ sophisticated econometric procedures to validate the approach, but some illustrative statistical tests are applied in Sections 5 and 6 (with further results given in Annex C). Some tentative conclusions are drawn in the final section.

\section{The "early warning indicators" literature}

The increasing incidence of financial "crises" - disturbances in financial markets of sufficient size to cause significant disruption to the real economy - has led to increasing work in this area. The use of aggregate indices of country risk has been widespread in the private and public sectors for some time. Some bank supervisors calculate country risk weights for domestic banks to apply to their lending abroad. The banks themselves evaluate country risk as part of their credit assessment and monitoring, although they usually do not make such ratings public. The World Bank uses risk-rating models to assess its country credit risk. The IMF has been developing 'macroprudential indicators' as part of a programme to strengthen the international financial structure. ${ }^{2}$ Export credit/insurance agencies

1 The term "emerging economies" is used in this paper to refer to the more important financial markets outside the longerstanding OECD members. This shorthand notation is a common usage in financial markets, but somewhat anachronistic given the size and sophistication of financial centres such as Hong Kong and Singapore.

2 See Evans et al (2000). 
calculate country-specific risk premia. Rating agencies produce sovereign risk ratings. The OECD has a framework for classifying non-member countries into seven risk categories as part of the "Knaepen Package", which seeks convergence in the international pricing of export credits. ${ }^{3}$ The framework encompasses four groups of variables: financial indicators, particularly indebtedness and projections of future debt service obligations; macroeconomic indicators; debt servicing record (e.g. rescheduling in the Paris Club); and political factors. A major characteristic of the OECD model is the use of flexible weights: for example, a poor score on debt-related variables will lead to a poor score overall, irrespective of what the other indicators show.

Most of these scoring systems have been based on indicators chosen on an ad hoc judgmental basis. But starting in the 1990s there has been an explosion in studies of "early warning indicators". These seek to discriminate more rigorously among competing indicators and select (and weight) those most useful in predicting crises. Three different approaches have in general been followed, with some studies using more than one approach:

- Qualitative comparisons, graphically comparing economic fundamentals immediately preceding a financial crisis with those in normal times or in a "control" group of countries which did not suffer a crisis. Aziz et al (2000), Caramazza et al (2000), Eichengreen, Rose and Wyplosz (1995), Eichengreen and Rose (1998), Frankel and Rose (1996), Glick and Moreno (1999), IMF (1998b) and the first part of Kaminsky and Reinhart (1999) employ this approach.

- Econometric modelling, either using regressions to explain some measure of exchange rate pressure or logit or probit models to test whether indicators are associated with a higher probability of a financial crisis. Caramazza et al (2000), Corsetti et al (1998), Demirgüç-Kunt and Detragiache (1998), Deutsche Bundesbank (1999), Eichengreen and Rose (1998), Eichengreen et al (1995), Frankel and Rose (1996), Glick and Moreno (1999), Hardy and Pazarbaşioğlu (1998), IMF (1998b), Kruger et al (1998), Milesi-Ferritti and Razin (1998), Persaud (1998), Sachs et al (1996) and Tornell (1999) are examples of this approach.

- Non-parametric estimation, evaluating the usefulness of a number of different variables in signalling a pending or potential crisis. Threshold values are chosen for each indicator so as to strike a balance between the risk of many false signals and the risk of missing the crisis altogether. Edison (2000), Goldstein (1998), Goldstein et al (2000), Kaminsky, et al (1998), Kaminsky (1999) and the second part of Kaminsky and Reinhart (1999) use this approach. 3 The classification of individual countries is not made public but the process is described at
www.oecd.org/ech/act/xcred/knaepen-package-en.htm. 
A good summary of this literature, as it stood prior to the Asian crisis, is in Kaminsky et al (1998), which originally appeared as an IMF working paper in July 1997. They reviewed 28 studies of currency crises, which between them tested 105 possible indicators, of which 43 are significant in at least one study. The most important indicators were international reserves, the real exchange rate, credit growth, inflation and real GDP (either growth or relative to trend). In contrast to the attention it has been given since the Asian crises, the size and composition of external debt was rarely found to be a useful indicator in these studies. The first column of Table 1 summarises the results of their survey while the subsequent columns cover a number of subsequent studies.

Table 1

Indicators of financial crisis

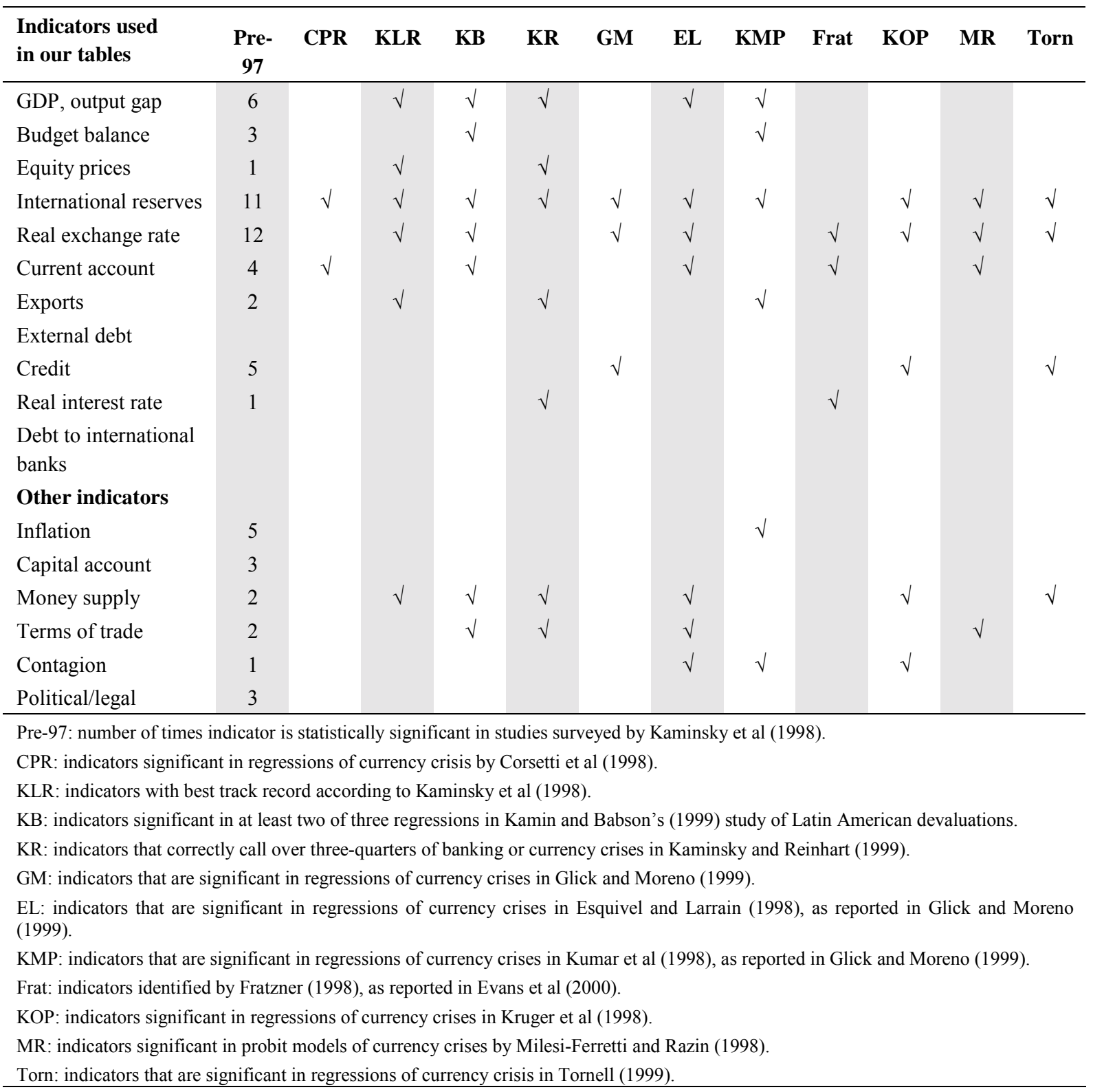




\begin{tabular}{|c|c|c|c|c|c|c|c|c|c|c|c|}
\hline \multicolumn{12}{|c|}{$\begin{array}{l}\text { Table } 1 \text { (cont) } \\
\text { Indicators of financial crisis }\end{array}$} \\
\hline $\begin{array}{l}\text { Indicators used } \\
\text { in our tables }\end{array}$ & DD* & HP* & ER* & Ros* & GKR* & Gold & JPM & $\begin{array}{c}\text { IMF } \\
\text { indices }\end{array}$ & $\begin{array}{l}\text { IMF } \\
\text { WEO }\end{array}$ & $\begin{array}{l}\text { IMF } \\
\text { ICM }\end{array}$ & $\begin{array}{l}\text { IMF } \\
\text { EWS }\end{array}$ \\
\hline GDP, output gap & $\sqrt{ }$ & $\sqrt{ }$ & $\sqrt{ }$ & $\sqrt{ }$ & $\sqrt{ }$ & $\sqrt{ }$ & & & $\sqrt{ }$ & & \\
\hline Budget balance & & & $\sqrt{ }$ & & & & & $\sqrt{ }$ & & & \\
\hline Equity prices & & & & & $\sqrt{ }$ & $\sqrt{ }$ & $\sqrt{ }$ & & $\sqrt{ }$ & & \\
\hline $\begin{array}{l}\text { International } \\
\text { reserves }\end{array}$ & & & & & & $\sqrt{ }$ & $\sqrt{ }$ & $\sqrt{ }$ & $\sqrt{ } \sqrt{ }$ & $\sqrt{ }$ & $\sqrt{ }$ \\
\hline Real exchange rate & & $\sqrt{ }$ & $\sqrt{ }$ & & $\sqrt{ }$ & $\sqrt{ }$ & $\sqrt{ }$ & $\sqrt{ }$ & $\sqrt{ } \sqrt{ }$ & $\sqrt{ }$ & $\sqrt{ }$ \\
\hline Current account & & & & & & $\sqrt{ }$ & & $\sqrt{ }$ & $\sqrt{ }$ & $\sqrt{ }$ & $\sqrt{ }$ \\
\hline Exports & & & & & $\sqrt{ }$ & $\sqrt{ }$ & & $\sqrt{ }$ & & & $\sqrt{ }$ \\
\hline External debt & & & & & & & $\sqrt{ }$ & & & & $\sqrt{ }$ \\
\hline Credit & & $\sqrt{ }$ & & $\sqrt{ }$ & & & & $\sqrt{ }$ & $\sqrt{ } \sqrt{ }$ & $\sqrt{ }$ & \\
\hline Real interest rate & $\sqrt{ }$ & $\sqrt{ }$ & & & $\sqrt{ }$ & $\sqrt{ }$ & & & $\sqrt{ }$ & & \\
\hline $\begin{array}{l}\text { Debt to } \\
\text { international banks }\end{array}$ & & & & & & & & $\sqrt{ }$ & & & \\
\hline Other indicators & & & & & & & & & & & \\
\hline Inflation & $\sqrt{ }$ & $\sqrt{ }$ & & & & & & & $\sqrt{ }$ & & \\
\hline Capital account & & & & & & & & & & & \\
\hline Money supply & & & & & $\sqrt{ }$ & $\sqrt{ }$ & & $\sqrt{ }$ & $\sqrt{ } \sqrt{ }$ & & \\
\hline Terms of trade & $\sqrt{ }$ & & & & & & & & $\sqrt{ }$ & & \\
\hline Contagion & & & & & & & $\sqrt{ }$ & & $\sqrt{ }$ & & \\
\hline Political/legal & $\sqrt{ }$ & & & & & & & & & & \\
\hline \multicolumn{12}{|c|}{ * These studies focus on banking crises. } \\
\hline \multicolumn{12}{|c|}{ DD: indicators significant in regressions of banking crises in Demirgüç-Kunt and Detragiache (1998). } \\
\hline \multicolumn{12}{|c|}{ HP: indicators significant in regressions of banking crises in Hardy and Pazarbaşioğlu (1998). } \\
\hline \multicolumn{12}{|c|}{ ER: indicators significant in Eichengreen and Rose (1998). } \\
\hline \multicolumn{12}{|c|}{ Ros: indicators significant in regressions of banking crises in Rossi (1999). } \\
\hline \multicolumn{12}{|c|}{ GKR: indicators with lowest signal-to-noise ratios as predicators of banking crises in Goldstein et al (2000). } \\
\hline \multicolumn{12}{|c|}{ Gold: indicators with best track record according to Goldstein (1998). } \\
\hline \multicolumn{12}{|c|}{ JPM: indicators used in JP Morgan's model purporting to predict currency crashes in emerging economies. See Persaud (1998). } \\
\hline \multicolumn{12}{|c|}{ IMF indices: indicators included in composite indicators of vulnerability in IMF (1999b). } \\
\hline \multicolumn{12}{|c|}{$\begin{array}{l}\text { IMF WEO: indicators showing abnormal behaviour prior to financial crises in IMF (1998b). Those marked with a double tick were the } \\
\text { most significant in probit regressions and used to construct an index of vulnerability to currency crisis. }\end{array}$} \\
\hline IMF ICM: indicators $n$ & ioned as & redicti & urrency & d banki & crises in & ne brief & erature s & rvey on $\mathrm{p}$ & 43 of IM & $(1999 a)$ & \\
\hline
\end{tabular}

There has been comparable econometric work on banking crises. ${ }^{4}$ The two strands are related, as many analyses (see, for example, Kaminsky and Reinhart (1999) and Glick and Hutchison (2000)) have concluded that banking crises may lead to currency crises in emerging economies and perhaps vice versa. Demirgüç-Kunt and Detragiache (1998) conclude that banking crises "tend to erupt when the macroeconomic environment is weak, particularly when growth is low and inflation is high. Also, high

4 The interest in this paper is in studies that attempt to identify those macroeconomic factors that cause a systemic banking crisis. Another, less developed, strand of literature looks at factors determining those individual banks more likely to fail during a crisis. See González-Hermosillo (1999). 
real interest rates are clearly associated with systemic banking sector problems". Hardy and Pazarbaşioğlu (1998) add to this list of potential causal factors: credit expansion, capital inflow, sharp declines in the real exchange rate and adverse trade shocks. They comment that banks' foreign borrowing was a particularly significant factor in the Asian crisis. Rossi (1999) constructs an index of prudential regulation; he finds better supervision reduces the incidence of banking crises. Eichengreen and Rose (1998) stress the importance of real interest rates in the advanced economies in putting strain on banking systems in the emerging markets. Low rates may encourage fund managers to move into emerging economies but when real rates rise in the advanced economies they repatriate funds. This causes a liquidity problem in the emerging economies at a time when their balance of payments is particularly vulnerable (as the high real interest rates also reduce demand in the emerging economies' export markets) and their companies are facing higher debt service obligations. Based on the studies summarised in Table 1, the most important causes of banking crises are overvalued exchange rates, inadequate international reserves, recessions, high real interest rates and excessive credit growth.

These econometric exercises continue to be refined, both by better procedures and by gathering more and better data. Leading indicator models are still in their infancy (or at least their adolescence). Many of the current models only distinguish between a crisis and no crisis, rather than degrees of severity of financial problems. No doubt researchers are currently adding the recent Russian and Brazilian turmoil to their data sets and finding new indicators to predict these crises. Possible directions for future research would include making more use of the international banking statistics compiled by the BIS. ${ }^{5}$ Also, some approximate quantification could be attempted for potentially relevant influences such as central bank independence, political stability and the quality of supervision. Some would argue for greater attention to political variables, on the grounds that market sentiment can be greatly influenced by them. ${ }^{6}$ If information about the activities of large investors could be compiled, this would make a further useful addition to the list of indicators. The role of contagion could be investigated further. A financial crisis occurring elsewhere, particularly in a large or nearby country, has been found to raise the probability of a crisis in the domestic economy, but opinions differ about the mechanism of contagion. ${ }^{7}$ It may operate through trade or credit links, because they have common lenders, ${ }^{8}$ or it may arise because (perceived) macroeconomic similarities alarm foreign investors or because large institutional investors, or credit rating agencies on whose opinion they base portfolio choices, lump all emerging markets (in a region) together. These channels have different implications for the best way

5 See Hawkins (1999) on how the Asian crisis would have been less of a surprise if more attention had been paid to these data.

6

The Economist Intelligence Unit accords political factors a 40\% weighting in its credit rating processes. The IMF (1999a, p 149) comments that rating agencies' "emphasis on political factors as much as economic ones seems appropriate". On the other hand, political factors were argued to add little information in tests by Haque et al (1998).

7 Examples include Eichengreen et al (1996) for advanced economies and Frankel and Rose (1996) for emerging markets.

8 See Van Rijckeghem and Weder (1999). 
of constructing a contagion variable. The existence of an IMF programme may help fend off or reduce the severity of crises, according to a recent econometric study by Bussière and Mulder (1999).

While Table 1 does reflect some consensus regarding the econometric evidence, it also illustrates the substantial disagreement about which indicators matter, let alone what weight should be accorded to each. And as with investment advice, it should be warned that "past performance is no guarantee of future performance". Berg and Pattillo (1999) ask the question: "if we had been using these models 9 in late 1996, how well armed would we have been to predict the Asian crisis?" They conclude "the results are mixed. Two of the models fail to provide useful forecasts. One model provides forecasts that are somewhat informative although still not reliable." A comparable study by Furman and Stiglitz (1998) and an informal survey by The Economist (1998) reach similar conclusions. Part of the reason is that the indicators that seem most relevant in explaining one crisis are often not germane to the next crisis. As Glick and Moreno (1999) point out, crises in the more open Asian economies are more likely to result from competitiveness problems while in Latin America internal monetary problems or commodity prices are a more likely cause. Mexico's was a crisis of government finance, while east Asia's was one of private sector finance. Economists are often like old generals fighting the last war. In reflecting on their own work on early warning signals for emerging economy crises, Goldstein et al (2000, p 104) say "while we would not place much confidence in the precise estimated ordering of vulnerability across countries, we think the signals approach looks promising for making distinctions between the vulnerability of countries near the top of the list and those near the bottom - that is, it may be useful as a 'first screen' which can then be followed by more in-depth country analysis". This attitude is totally consistent with the approach taken in this paper.

\section{The approach adopted}

There is no precise statistical measure of a crisis. But it is conceptually useful to think of a crisis as excessive pressure in financial markets, which has been triggered by various developments in a vulnerable economy. The most obvious sign that an economy is under pressure; that is suffering a loss of confidence, or a speculative attack, that may be the first stage of a financial crisis; is a large depreciation of its exchange rate. However, if the macroeconomic fundamentals are otherwise sound, the authorities may be able to deflect the impact on the exchange rate, at least for a time, by some combination of raising interest rates and running down international reserves. For this reason, the indicators employed in this work to construct the index of pressure encompass three elements; the exchange rate, interest rates and international reserves.

9 Three models developed before the Asian crisis; Frankel and Rose (1996), Kaminsky et al (1998) and Sachs et al (1996). 
Financial market pressures may be triggered by political events, natural disasters or contagion. However, all of these are largely unpredictable. This is true even in the most developed markets; more than a decade on it is still unclear why equity prices should have been a third lower at the end of October 1987 than at the start. Contagion is obviously important in triggering crises and the Asian experience in 1997 suggests this may be driven more by sentiment than by the more readily quantifiable trade linkages. ${ }^{10}$

But often a crisis will occur after a gradual deterioration in various aspects of the real economy and/or the financial sector which make the economy more susceptible to shocks. Such increases in vulnerability are observable and in this paper we try to construct indices to assist in monitoring them. Even then, results from a limited set of indicators are suggestive rather than definitive. To overcome this problem, the paper uses quantitative methods to identify those economies most deserving a closer study. This closer study involves not just examining a wider array of economic data but an assessment of non-quantitative and non-economic factors as well.

In terms of the theoretical literature, "first generation" models initiated by Krugman (1979) emphasise the role of fundamentals, especially fiscal laxity, in bringing about a crisis. The "second generation" models, surveyed by Flood and Marion (1998), allow for multiple equilibria and "self-fulfilling crises", and show that a crisis is not inevitable in a vulnerable economy. The latter models are therefore more consistent with the approach adopted here, which measures both whether an economy is currently under pressure and whether it has vulnerabilities that might may lead to pressure later on.

As a first step in our approach, four summary tables covering 24 economies have been prepared for a trial monitoring exercise. An introductory table shows consensus GDP growth forecasts and spreads in bond markets. The three core tables show current and previous values of three composite indices and the current values of their component indicators. The format is shown in Annex A. The first of the core tables has a monthly index of pressures manifest in financial markets. Continuing the earthquake analogy with which the paper opened, it is the equivalent of a Richter scale. The next two look for stresses in the tectonic plates as signalled by indices of vulnerabilities in the external and banking sectors, respectively. These tables are presented quarterly, in part due to limitations of data availability.

For several reasons it was decided not to distil this information into a single aggregate index of risk. These include the problem of information about the individual underlying indicators being obscured. As discussions among experts turn on such variables, this can be an important shortcoming. Furthermore, the nature of risks varies and it is inappropriate to "consolidate" different types of risk

10 See Goldstein and Hawkins (1998), pp 30-2. 
into one number. For example, some countries' external financing situation can be viable even if their internal banking system may be insolvent. ${ }^{11}$

\section{Further issues concerning indicators, economies and weights used}

This section gives more detail about the construction and presentation of the summary tables shown in Annex A. The detailed scoring system used is outlined in Annex B. The general ideas behind the scoring are that (i) each index is a weighted sum of the scores of each individual indicator; (ii) the weights are chosen so that the maximum (worst) value of each index is 10; (iii) scores for each indicator generally range from minus 2 for an observation suggesting little risk, (eg a low external debt/GDP ratio) to plus 2 (eg a high debt ratio), ${ }^{12}$ and (iv) weights attaching to each score can vary, with extreme levels of certain key indicators (eg very high external debt/reserves ratios) getting increased weight.

The indicators were chosen and the weights applied judgementally, but after consultation with experts and after reviewing the available literature. For simplicity, the same weights were applied to every economy, rather than, for example, distinguishing between different exchange rate regimes and degree of openness in choosing the weight to assign the exchange rate. On the face of it, this approach may be regarded as "arbitrary". But on balance, we view it as best suiting our limited aim:

- $\quad$ while econometrics could be used to select the indicators and weights, Table 1 shows that different econometric exercises give different conclusions. Judgementally choosing just one study as definitive would be just as arbitrary as choosing the indicators themselves;

- furthermore, indicators found most useful in econometric studies of past crises are not necessarily the best ones for constructing indices of present dangers. Indices of vulnerability need to contain timely data. This is why, for example, we use just the BIS international banking data in this work whereas if we were doing an econometric study of past crises we might prefer a broader measure of international debt which becomes available much later;

- we put importance on simple, transparent techniques which make it clear what is driving the results, rather than a complex 'black box'.

11 A subsequent IMF (1999b) study has also constructed a number of composite indices, but not an overall index, a move endorsed by participants at a recent IMF seminar. IMF (1999b, p 79) describes its summary indices, which cover external imbalance, domestic macroeconomic imbalances, portfolio spillovers, reserve adequacy, trade spillover and financial vulnerability. See also Table 1 above, which lists most of the component indicators used. See also Hilbers et al (1999).

12 However, for some indicators no negative scores are given or only minus 1 is scored. 
The first core table (A1) includes indicators of exchange market pressure: changes in the exchange rate, in interest rates and in foreign exchange reserves. The latest values of these three indicators are shown in italics on the right-hand side of the table. This idea of combining three manifestations of exchange market pressures was pioneered by Eichengreen et al (1995).

Many subsequent studies, even as recent as Caramazza et al (2000), Edison (2000), Glick and Hutchison (2000) and IMF (2000), omit interest rates either because the data are hard to find or because they cover periods where interest rates were controlled rather than market-determined. However, leaving out interest rates would mean that, in cases such as Argentina and Hong Kong where fixed exchange rates were successfully defended, the index would markedly understate the degree of pressure. The interest rate definition used in this paper is based on the real rate of interest. This created an anomaly in the case of China, where real rates are high because of declining prices and not because nominal rates have been raised to defend the exchange rate. However, experiments with the obvious alternative - nominal interest rates - produced rather more apparent anomalies. The highest risk weight is given to real interest rates over $4 \%$. For most (but not all) economies, real interest rates over $4 \%$ are likely to exceed the trend rate of economic growth, making debt/GDP ratios explosive.

The exchange rate enters this index twice, once as a change over three months and once as a change over one year. The reasons for this approach are: (i) to give greater weight to more recent exchange rate movements but (ii) to discount a reversal of a sharp exchange rate movement a year earlier. As mentioned above, appreciations of the exchange rate are scored minus one or two. It could be argued that beyond a certain point an appreciation becomes excessive and should be scored as adding to risk. $^{13}$

The data on reserves are admittedly imperfect and, during the run-up to the Asian crisis, the published data were actually misleading; in some cases, they omitted off-balance-sheet transactions that had reduced the amount of reserves available for the defence of a besieged currency. ${ }^{14}$ This should not be a problem in future. The prescriptions for international reserves data in the IMF's Special Data Dissemination Standard were significantly strengthened in March 1999 to follow a template developed in conjunction with the Committee on the Global Financial System. ${ }^{15}$ Ideally, the measure would

13 Another possible modification would be to distinguish between a preannounced depreciation through a crawling peg and an unexpected devaluation.

14 The Working Group on Transparency and Accountability (1998, pp 15-6), comment that "following the flotation of its exchange rate on 2 July 1997, Thailand revealed that although the central bank held gross reserves of US\$ 32 billion at the end of June, outstanding forward and swap liabilities totalled US\$ 29 billion. In Korea, the central bank reported that gross reserves totalled US\$ 24 billion at the end of November, but almost two-thirds of this amount was not readily available to the Korean authorities because it had been deposited with overseas branches of Korean banks to assist the banks in meeting their external obligations."

15 See CGFS (1998a, b). By September 2000, 31 of the 47 SDDS subscribers were adhering to the template. 
distinguish between the reasons for growth in reserves, with reserves accumulating due to short-term capital inflows offering less reassurance. However, in practice the data needed to make such distinctions is not available quickly enough.

The second core table (A2) summarises some indicators of countries' external vulnerability. ${ }^{16}$ The first two measures of underlying external disequilibria include a high real effective exchange rate or current account deficit, while the third is based on recent export growth, as a slowdown in exports has frequently preceded crises. For the exchange rate and export growth, the indicators are expressed relative to a base period. The choice of the base period is inevitably somewhat arbitrary. There is a trade-off between choosing a single recent year, which may be unrepresentative, or a longer-term average that might not reflect longer-term structural changes. One possibility is to choose a period regarded as "normal" or an "equilibrium". This is very difficult, especially without the benefit of hindsight. Also, a normal period for one region may be abnormal in another; yet using different time periods as bases for different countries would involve adding more complexity. The decision taken here is to go for a reasonably long period, 1990-98.

The final three indicators cover external debt. BIS data on liabilities to international banks and on international bonds outstanding are available more frequently, are more timely, and are more internationally comparable than data on other forms of external debt. Moreover, such flows tend to dominate year-to-year movements in the capital account - in the Asian crisis they displayed large movements in and out. In the calculation of debt/GDP ratios, GDP is converted into US dollars at a "smoothed" exchange rate. ${ }^{17}$

The final core table (A3) covers indicators of banking system vulnerability. Unfortunately, this is an area where reliable data are hard to find. In principle, it would be desirable to have indicators such as the quality of the supervisory system, the level of banks' non-performing loans, capital ratios, sectoral credit concentration and banks' exposure to foreign exchange or interest rate risk. In practice, however, such data are either not widely available or are systematically distorted (e.g. low reported NPLs often reflect negligent supervision). It was therefore decided to use five proxies for banking system vulnerability:

- the first is simply based on the rate of growth of domestic bank credit: very rapid growth has often gone hand in hand with declining loan standards/greater risk; ${ }^{18}$

16 Bussière and Mulder from the IMF have adopted a very similar set of indicators (see the column headed IMF EWS in Table 1) in their early warning system of external vulnerability.

17 The "World Bank Atlas" method is used. See Annex B for details.

18 A possible amendment would be also to penalise credit contraction, beyond some point, although this is sometimes a positive indication that banks are sorting out problems in their loan portfolios. 
- the second is the growth of borrowing from international banks, which typically reflects increased foreign currency borrowing by domestic residents (sometimes, as in many Asian economies, through local banks);

- $\quad$ a third, related, indicator measures the external borrowing by banks as a percentage to domestic credit. This is a proxy (admittedly a highly imperfect one) for the extent to which local bank lending is denominated in foreign currency: such lending leaves borrowers and their banks exposed to significant exchange rate risks; ${ }^{19}$

- the fourth indicator is the level of real interest rates; very high real rates mean banks will struggle to have loans repaid while very negative rates mean they will struggle to attract deposits;

- the final indicator used is "stand-alone" credit ratings of the leading banks. ${ }^{20}$ While in practice credit rating agencies' assessments have not been sufficiently prescient to make this a leading indicator of banks' condition, it is a useful coincident indicator and a likely influence on future funding costs. ${ }^{21}$

The indices of pressure and vulnerability have been modified during the year they have been in use. Some of these modifications just reflected data availability. Other changes involved respecifying indicators in the light of experience. For example, reserves and borrowing from foreign banks were both initially included as percentage changes. However, this meant that marginal increments to very low reserves were being unduly rewarded and higher international borrowing off a low base was being unduly penalised. The absolute increases are now expressed relative to the size of trade and GDP respectively.

Some indicators have been dropped or added as experience about their relevance has accumulated. Correlations were calculated between the different indicators in each group to check for redundant variables. The results, given in Table C1 in Annex C, generally suggest that each of the indicators retained contributes some additional information.

Views on the utility of various indicators, and the indices constructed from them, were informed by observing the extent to which they correctly identified economies that suffered crises or gave

19 A possible counter-argument is that external borrowing may be higher in banking systems with high foreign ownership, which are arguably more stable.

20 These ratings differ from conventional ratings in that they assess the inherent strength of banks and do not take into account any outside support.

21

Possible extensions under consideration include structural variables such as the stringency of prudential requirements, the degree of foreign and state ownership and assessments of the quality of legal enforcement, and the independence and quality of bank supervision. Proxies for the quality of the loan book such as the proportion of loans to property developers, or to state-owned enterprises, could also be considered. As the quality of data on non-performing loans are improving, this could be added soon. 
"plausible" (or "misleading") indications of vulnerable economies. There were also more formal statistical tests. Both types of evidence are discussed below.

\section{Setting thresholds in the scoring process}

A continuous, but complex, scoring system could be employed to combine the values of the individual indicators into summary indices. However, the current arrangement of mapping values into five bands (see Annex B), given the values $-2,-1,0,1$ and 2 respectively, has the virtue of simplicity. It has been used by the Caisse des Dépots et de Consignations, among others, for this reason. It means that every indicator has a maximum worst score of two so that each one of the three indices has a maximum worst score of ten. It is thus easier to see which indicators are leading to a deterioration in an index for a country. However, realising the limitations of such an approach, undue emphasis is not placed on single-point changes in index scores which may be the result of very small changes in indicators that cross the threshold from one band to another.

The choice of the thresholds between the bands is bound to be somewhat arbitrary. Clearly, if too many observations fall into the same band, the variable will not be sufficiently discriminating. Over a long run of observations, the distribution across the bands might be expected to be symmetric and centred around the neutral "zero" band. Although it is an open question whether the distribution should be normal, fatter-tailed, or uniform, the recent past has been abnormal and it is quite reasonable that the results should have been somewhat skewed. Table C2 in Annex C shows the distribution of the scores for each component indicator.

- $\quad$ Among the exchange market pressure indicators, only the short-run exchange rate movement seems unduly concentrated, in the zero band. This implies that the currencies covered rarely move more than $3 \%$ in a quarter. Narrowing the thresholds to say $1 \%$ would highlight trivial fluctuations, while excluding economies with fixed exchange rates makes the distribution more uniform.

- Among the external position indicators, the distributions do not seem unduly concentrated in any single band.

- $\quad$ The banking indicators are more prone to bunching as they are confined to only three bands rather than five, reflecting their asymmetric character. Banks expanding credit rapidly are riskier but this does not mean that rapidly contracting credit is a good thing. However, only two of them have more than half their observations in one band.

An alternative considered was to push the distribution into a normal distribution by subtracting the mean and dividing by the standard deviation of each indicator and then defining bands as $<-1.5,-1.5$ to $-0.5,-0.5$ to $0.5,0.5$ to 1.5 and $>1.5$. This would make the method less transparent as instead of 
round numbers, the edges of the bands would be non-integers. It would also raise the question of the time period over which to do the normalisation and how often it should be recalculated. Furthermore, as noted above, it may not be appropriate to assume the indicators are normally distributed. There is evidence that some financial data have "fatter tails"(ie more extreme observations). They may not even be symmetric: for example, equity prices fell by a third in a couple of days in October 1987 but have never increased this rapidly.

\section{Country coverage}

About two dozen countries seemed a tractable number to monitor. Lists of the 20 most important emerging economies were tabulated on nine different criteria. Some reflected the sheer size of the individual economy and others the indirect impact a crisis there might have on other economies. The criteria were nominal GNP (converted at current exchange rates), real GNP (converted using PPPs), importance as an export market for the G10, borrowing from advanced economies' banks, global bonds outstanding, equity market capitalisation, cross-border equity trades, foreign direct investment and imports from emerging economies (as an indicator of contagion potential). There was, unsurprisingly, a large degree of overlap between the lists. Calculating 20 places on nine criteria meant there were 180 cells in total. The 24 emerging economies covered in the tables account for 162 of these 180 cells. Most of the remaining positions are filled by middle eastern countries, but no single uncovered country appears often.

\section{Weighting}

As mentioned above, each index is a weighted sum of the scores of individual indicators. The size of the weights depend on the number of indicators used to construct the index so that each index has a maximum value of ten. The indicators are generally equally weighted, although where certain key indicators reach extreme values they are given increased weight (Annex B). This reflects a preference for a simple system where it is easy to see which indicators are causing changes in the indices. An alternative considered, less arbitrary but more complex, is to weight indicators in inverse proportion to their volatility. ${ }^{22}$ This would have similar advantages and drawbacks as the normalisations of indicators considered above. 


\section{Review of the indices}

As an illustration, the six economies scoring highest (ie worst) on the exchange market pressure index at various points of time during 1996-98 are shown in the upper part of Table 2. The scores of economies generally regarded as having experienced "crises"(ie the five Asian economies, Russia and Brazil) but were not under pressure at the time are shown in italics in the lower part of the table. As expected, the pressure index acts as a coincident indicator. The Asian crisis hit between the middle and end of 1997 and those countries affected show large rises in the pressure index at this time.

Table 2

Results for index of exchange market pressure*

\begin{tabular}{|c|c|c|c|c|c|c|c|}
\hline & Problem countries & 1996Q2 & 1997Q2 & 1997Q4 & 1998Q2 & $1998 Q 3$ & 1998Q4 \\
\hline & & ZA (9) & TH (7) & ID (9) & RU (6) & ZA (10) & TR (10) \\
\hline & & $\mathrm{CO}(5)$ & BR (7) & PH(9) & CL (6) & BR (8) & PE (9) \\
\hline & & VE (5) & CZ (7) & MY (8) & ZA (6) & CL (8) & BR (8) \\
\hline & & HU (4) & TR (6) & KR (8) & $\mathrm{CN}(5)$ & HU (8) & $\mathrm{CO}(8)$ \\
\hline & & BR (3) & PE (5) & TH (8) & SG (5) & TR (8) & HU (8) \\
\hline & & TH (3) & KR (4) & BR (8) & TH (5) & TH (7) & RU (6) \\
\hline \multirow{4}{*}{$\begin{array}{l}\text { Memo } \\
\text { item: }\end{array}$} & \multirow{4}{*}{$\begin{array}{l}\text { Countries in crisis } \\
\text { (if not shown above) }\end{array}$} & $I D(3)$ & $I D(3)$ & $R U(7)$ & $B R(4)$ & $R U(6)$ & \\
\hline & & $R U(2)$ & $M Y(3)$ & & & & \\
\hline & & $K R(1)$ & $P H(2)$ & & & & \\
\hline & & $\begin{array}{c}P H(1) \\
M Y(-2)\end{array}$ & $R U(-1)$ & & & & \\
\hline
\end{tabular}

AR: Argentina; BR: Brazil; CL: Chile; CN: China; CO: Colombia; CZ: Czech Republic; HU: Hungary; ID: Indonesia; KR: Korea; MX: Mexico; MY: Malaysia; PE: Peru; PH: Philippines; RU: Russia; TH: Thailand; TR: Turkey; VE: Venezuela; ZA: South Africa.

* See Annex B for construction of index. Higher "scores" (shown in brackets) indicate greater pressure (maximum $=10)$.

Table 3 lists the economies with the most vulnerable external position. The table, and the middle panel of Graph 1, show the index would have done a good job of detecting the problem areas, showing that the Asian crisis economies were becoming more vulnerable from the beginning of 1996. In mid-1996, Thailand and Korea were at the top of the list with high scores. However, the index did not highlight Russia because its troubles did not primarily stem from current account imbalances. By late 1996 the average of the indicators for the crisis-hit Asian countries was around 6. The vulnerability of Latin America rose steadily from mid-1996 to end-1998, which also seems plausible given subsequent developments. 


\begin{tabular}{|c|c|c|c|c|c|c|c|}
\hline \multicolumn{8}{|c|}{$\begin{array}{c}\text { Table } 3 \\
\text { Results for index of external vulnerability* }\end{array}$} \\
\hline & Problem countries & 1996Q2 & 1997Q2 & 1997Q4 & 1998Q2 & 1998Q3 & 1998Q4 \\
\hline \multirow{10}{*}{$\begin{array}{l}\text { Memo } \\
\text { item: }\end{array}$} & \multirow{10}{*}{$\begin{array}{l}\text { Countries in crisis } \\
\text { (if not shown above) }\end{array}$} & $\mathrm{TH}(8)$ & MY (8) & $\operatorname{AR}(7)$ & AR (8) & AR (8) & CL (7) \\
\hline & & KR (7) & TH (8) & $\mathrm{CZ}(6)$ & CL (7) & CL (7) & AR (6) \\
\hline & & ZA (6) & $\mathrm{KR}(7)$ & ID (6) & $\mathrm{CO}(7)$ & $\mathrm{CO}(7)$ & $\mathrm{CZ}(6)$ \\
\hline & & MX (5) & ID (6) & KR (6) & ZA (6) & RU (7) & $\mathrm{CO}(5)$ \\
\hline & & AR (4) & MX (5) & MY (6) & $\mathrm{BR}(5)$ & CZ (5) & RU (5) \\
\hline & & ID (4) & $\mathrm{CZ}(5)$ & PH (6) & CZ (5) & ZA (5) & ZA (4) \\
\hline & & $M Y(3)$ & $B R(3)$ & $R U(4)$ & $R U(4)$ & $B R(3)$ & $B R(3)$ \\
\hline & & PH (3) & PH (3) & $B R(3)$ & & & \\
\hline & & $R U(3)$ & $R U(3)$ & $T H(3)$ & & & \\
\hline & & $B R(-2)$ & & & & & \\
\hline
\end{tabular}

Note: Country abbreviations as in Table 2 .

* See Annex B for construction of index. Higher "scores" (shown in brackets) indicate greater pressure (maximum $=10$ ).

The comparable results for the banking system vulnerability index are shown in the lower panel of Graph 1 and in Table 4. Reflecting the data problems mentioned above, the results are less impressive, but the index was warning of weaknesses in the Asian economies before they experienced the 1997 crisis. Brazil's banking system did not appear vulnerable before its currency crisis, consistent with the result of Kaminsky and Reinhart (1999) that currency crises generally lead banking crises.

\begin{tabular}{lllllll}
\hline \multicolumn{9}{c}{ Table 4} \\
\multicolumn{9}{c}{ Results for index of banking system vulnerability* } \\
\hline \\
\hline
\end{tabular}

Note: Country abbreviations as in Table 2.

* See Annex B for construction of index. Higher "scores" (shown in brackets) indicate greater pressure (maximum = 10). 
Graph 1

Summary indices

A: Exchange market pressure
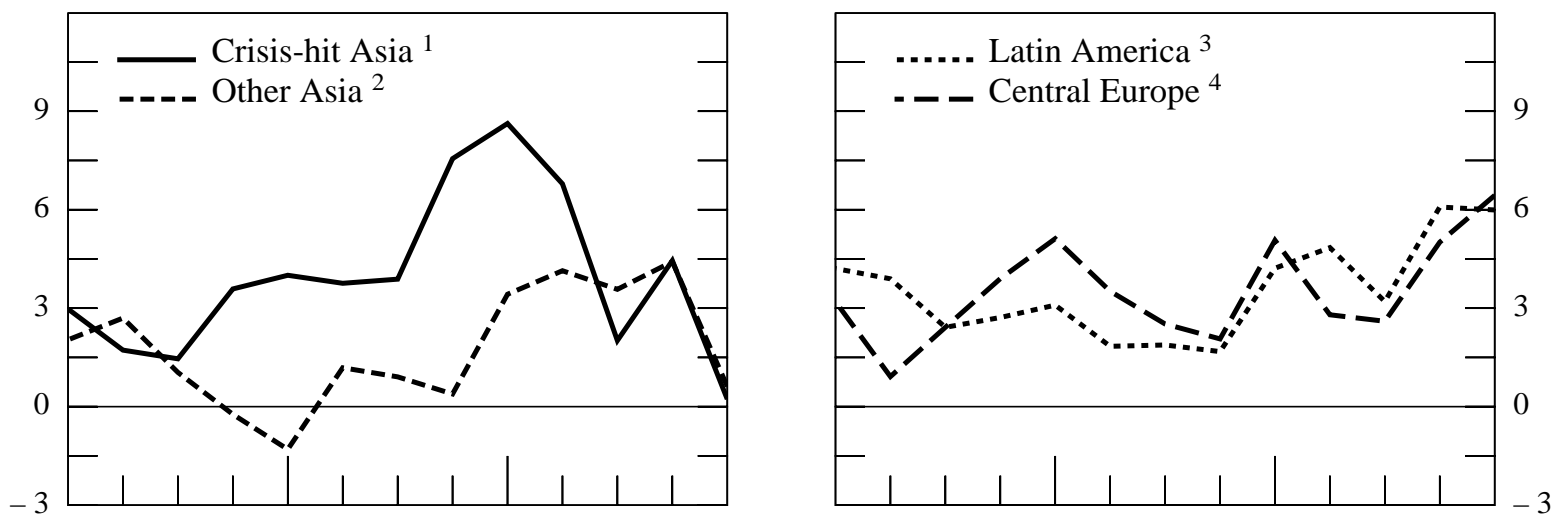

B: External sector vulnerability
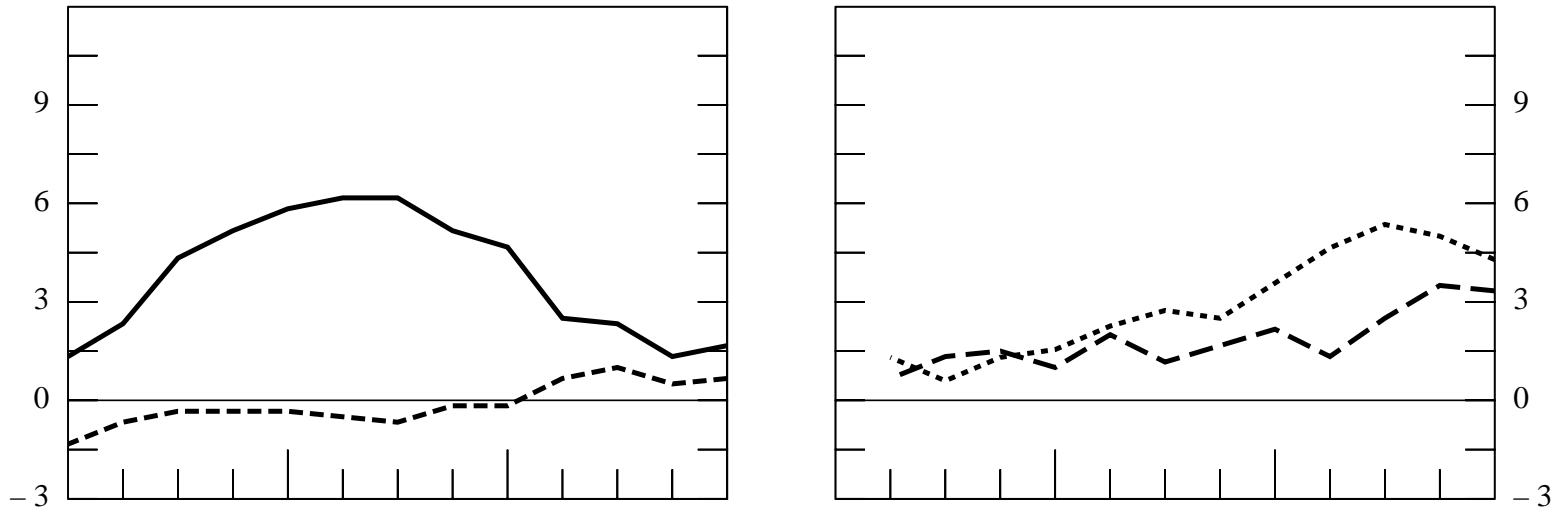

C: Banking sector vulnerability
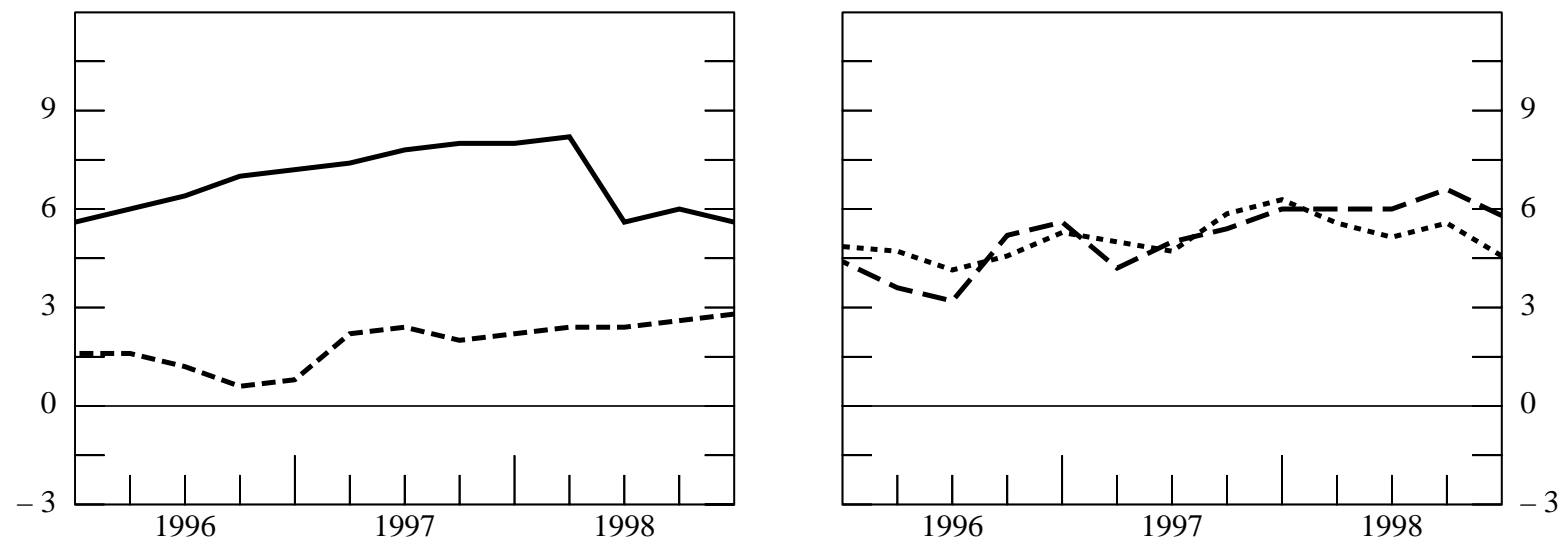

Note: Increases in the index (expressed as a simple average of the economies in each group) imply an increase in risk.

${ }^{1}$ Indonesia, Korea, Malaysia, the Philippines and Thailand. ${ }^{2}$ China, Hong Kong, India, Singapore and Taiwan. ${ }^{3}$ Argentina, Brazil, Chile, Colombia, Mexico, Peru and Venezuela. ${ }^{4}$ Czech Republic, Hungary, Poland, Russia and Turkey. 


\section{Statistical assessment}

As mentioned earlier, the lack of data mean the sample period in this work is too short to employ sophisticated econometric procedures to validate the approach. Nevertheless, a bit of descriptive analysis can illustrate various aspects and is given in this section.

First, some stylised facts of the exchange market pressure index are worth highlighting. Reflecting the sometimes volatile and skittish nature of financial markets, it has on occasion displayed rather erratic behaviour for individual countries (see Table 5). For example, the suddenness with which financial markets became hostile to Brazil and Mexico is shown in the large range between maximum and minimum values and the low degree of persistence (autocorrelation).

Table 5

Statistics on the exchange market pressure index

(1993-98)

\begin{tabular}{lcccccccc}
\hline$P_{t}$ & Brazil & Indonesia & Korea & Malaysia & Mexico & Philippines & Russia & Thailand \\
\hline Mean & 5.4 & 3.1 & 4.2 & 2.1 & 3.5 & 2.9 & 3.6 & 2.8 \\
$\begin{array}{l}\text { Standard } \\
\text { deviation }\end{array}$ & 1.9 & 2.5 & 2.0 & 2.7 & 2.9 & 2.9 & 3.0 & 3.3 \\
$\begin{array}{l}\text { Maximum } \\
\text { Minimum }\end{array}$ & 10.0 & 9.6 & 9.0 & 8.2 & 9.2 & 8.4 & 7.7 & 9.8 \\
$\begin{array}{l}\text { Auto- } \\
\text { correlation } \\
\text { with } P_{t-1}\end{array}$ & 0.17 & -2.5 & 1.0 & -2.1 & -1.3 & -2.1 & -1.7 & -1.7 \\
\hline
\end{tabular}

Given the volatile and unpredictable nature of financial markets, no set of fundamentals is going to explain the pressure index well. Nevertheless, it is interesting to assess whether economies scored as "vulnerable" have come under pressure later on. To this end, a simple econometric approach was employed where the exchange market pressure index $(P)$ is regressed on its own lagged value as well as on the indices of external vulnerability (Ext) and banking sector vulnerability (Bnk) using pooled quarterly data for the 24 emerging markets over the period 1993-98 and allowing for fixed effects. ${ }^{23}$ This not a rigorous test. For instance, it is recognised that the causal link between currency pressure on the one hand and banking- and external-sector vulnerability on the other is not unidirectional. The collapse of a currency could indeed deepen a banking crisis, thus activating a vicious spiral. Nor are the two explanatory variables totally independent; eg a consumption binge is likely to lead to both a deterioration in the current account and excessive credit growth. Both the exchange market pressure

23 Thus, the intercept was estimated separately for each individual country, while the slope coefficients were constrained to be the same across countries. 
index and the banking sector vulnerability index include the real interest rate. Notwithstanding these caveats, the regression is a useful descriptive device showing the relationship between the pressure and the vulnerability indices. As the length of the early-warning period cannot be taken to be the same for each currency crisis and for each variable examined, lags of up to eight quarters prior to currency turbulence were tested for $(E x t)$ and $(B n k) .^{24}$

$$
P_{t}=\alpha+\beta_{1} P_{t-1}+\beta_{2} E x t_{t-i}+\beta_{3} B n k_{t-j}+u_{t}, \text { with } i \text { and } j=1,2, \ldots, 8
$$

Table 6

Fixed effects panel regression (dependent variable: $P$ )

1993-98

\begin{tabular}{|c|c|c|}
\hline & All countries & Crisis countries \\
\hline \multirow{2}{*}{$P_{t-1}$} & 0.38 & 0.29 \\
\hline & $(8.43)$ & $(3.95)$ \\
\hline \multirow{2}{*}{$E x t_{t-2}$} & 0.13 & 0.22 \\
\hline & (2.59) & $(2.51)$ \\
\hline \multirow{3}{*}{$B n k_{t-4}$} & 0.25 & 0.38 \\
\hline & (2.98) & $(2.82)$ \\
\hline & $\mathrm{R}^{2}(0.37)$ & $\mathrm{R}^{2}(0.35)$ \\
\hline \multirow{2}{*}{$P_{t-1}$} & 0.40 & 0.34 \\
\hline & (8.89) & $(4.45)$ \\
\hline \multirow{2}{*}{$E x t_{t-4}$} & 0.02 & 0.12 \\
\hline & $(0.37)$ & $(1.12)$ \\
\hline \multirow{3}{*}{$B n k_{t-4}$} & 0.30 & 0.38 \\
\hline & $(3.45)$ & (2.39) \\
\hline & $\mathrm{R}^{2}(0.36)$ & $\mathrm{R}^{2}(0.32)$ \\
\hline \multirow{2}{*}{$P_{t-1}$} & 0.39 & 0.38 \\
\hline & $(7.71)$ & $(4.45)$ \\
\hline \multirow{2}{*}{$E x t_{t-8}$} & 0.02 & -0.03 \\
\hline & $(0.35)$ & $(0.26)$ \\
\hline \multirow{3}{*}{$B n k_{t-4}$} & 0.29 & 0.45 \\
\hline & (3.08) & (3.02) \\
\hline & $\mathrm{R}^{2}(0.36)$ & $\mathrm{R}^{2}(0.33)$ \\
\hline \multirow{2}{*}{$P_{t-1}$} & 0.41 & 0.34 \\
\hline & $(8.75)$ & $(4.31)$ \\
\hline \multirow{2}{*}{$E x t_{t-4}$} & 0.08 & 0.23 \\
\hline & $(1.47)$ & $(2.26)$ \\
\hline \multirow{3}{*}{$B n k_{t-2}$} & 0.07 & 0.10 \\
\hline & $(0.84)$ & $(0.73)$ \\
\hline & $\mathrm{R}^{2}(0.35)$ & $\mathrm{R}^{2}(0.37)$ \\
\hline
\end{tabular}

Note: t-statistics in parentheses.

This is in keeping with much of the literature though, admittedly, there is a certain arbitrariness in this choice. For example, Goldstein et al (2000) use a 24-month window for balance-of-payments crises and 12 months for banking crises. 
Equation (1) was estimated for both the full sample and a reduced sample of those countries which had suffered a crisis (ie Mexico, five Asian countries, Russia and Brazil). As Table 6 shows, for the appropriate lag structure, the coefficients on $(E x t)$ and $(B n k)$ are statistically significant and have the expected sign; ie the risk assessment provided by the two vulnerability indices seems to have some "predictive" power over and above the influence of $\left(P_{t-1}\right)$ in terms of a subsequent increase in the pressure variable.

As suggested by the autocorrelation in Table 5 and implied by its construction, there is persistence in the pressure index and so the coefficient on $\left(P_{t-1}\right)$ is, in all cases, highly significant. This seems to be invariant to the lag length on $(E x t)$ and $(B n k)$. While the explanatory power of the regression derives in large part from this persistence and the intercepts estimated for each individual equation, the results are consistent with the notion that prolonged fundamental disequilibria can trigger exchange rate pressure. In other words, crises are not just random accidents.

If a longer run of data were available covering a period of reasonable structural stability, the composition of the vulnerability indices might be refined by seeing which components appear most closely associated with subsequent financial market pressure. At present, we do not have sufficient data for a rigorous evaluation along these lines but as an illustrative exercise the statistical significance of the individual indicators underlying the vulnerability indices is shown in Table 7. The pooled estimates started with the "full" equation specification (Equation 2), where all indicators were entered individually. It was then reduced to an equation, where the indicators with the least statistically significant coefficients were been progressively deleted.

$$
\begin{aligned}
& P_{t}=\alpha+\beta_{1} P_{t-1}+\beta_{2} \text { reer }_{t-2}+\beta_{3} g x_{t-2}+\beta_{4} c g d p_{t-2}+\beta_{5} \text { debt }_{t-2}+\beta_{6} \text { gdebt }_{t-2} \\
& +\beta_{7} \text { stdebt }_{t-2}+\beta_{8} r_{t-4}+\beta_{9} d c e_{t-4}+\beta_{10} \text { bis }_{t-4}+\beta_{11} \text { bisdc }_{t-4}+\beta_{12} \text { bkrat }_{t-4}+u_{t}
\end{aligned}
$$

For both country samples, the indicators within the composite indices in (1) that have most explanatory and leading power are the real effective exchange rate for the index of external sustainability and the real interest rate for the index of banking vulnerability. These results are fully in line with other studies on early-warning indicators. An excessive real appreciation of a currency implies a loss of external competitiveness, which may eventually require an adjustment in the nominal exchange rate. High real interest rates (likely to increase the credit risk faced by banks) seem to increase the probability of a banking and/or currency crisis. In addition, for the full country sample, countries with high ratios of external debt to GDP are found to be more prone to currency crises. As in many of the studies surveyed in Section 2, the coefficient on the current account balance turned out to be statistically insignificant. ${ }^{25}$ The domestic credit variable also performed poorly or was wrongly

25 This was also the case when we tried expressing the current account as a ratio to trade instead of GDP. 
signed, notwithstanding the emphasis placed by Kaminsky and Reinhart (1999) on this variable. Other studies have also found little evidence of an independent role of the credit variable. ${ }^{26}$ Another surprising result is that the ratio of short-term debt to foreign exchange reserves - the indicator most likely to signal a liquidity crisis - was only statistically significant for the reduced equation. The reason for this might be the low degree of volatility of the debt ratio, perhaps calling for the introduction of a more sophisticated mapping (threshold) system. Concerning the crisis countries, the statistical significance of liabilities to BIS reporting banks (as a percentage of domestic credit) as a leading indicator is in line with discussions of the driving forces of these crises. ${ }^{27}$

Table 7

Fixed effects panel regression (dependent variable: $P$ )

\begin{tabular}{|c|c|c|c|c|}
\hline & \multicolumn{2}{|c|}{ All countries } & \multicolumn{2}{|c|}{ Crisis countries } \\
\hline & Full & Reduced & Full & Reduced \\
\hline$P_{t-1}$ & $\begin{array}{c}0.38 \\
(8.48)\end{array}$ & $\begin{array}{c}0.41 \\
(9.90)\end{array}$ & $\begin{array}{c}0.19 \\
(2.19)\end{array}$ & $\begin{array}{c}0.28 \\
(3.59)\end{array}$ \\
\hline reer $_{t-2}$ & $\begin{array}{c}0.75 \\
(4.14)\end{array}$ & $\begin{array}{c}0.82 \\
(5.05)\end{array}$ & $\begin{array}{c}1.16 \\
(3.63)\end{array}$ & $\begin{array}{c}1.25 \\
(4.85)\end{array}$ \\
\hline$g x_{t-2}$ & $\begin{array}{c}0.01 \\
(0.07)\end{array}$ & & $\begin{array}{c}0.12 \\
(0.78)\end{array}$ & \\
\hline$c g d p_{t-2}$ & $\begin{array}{c}0.22 \\
(1.51)\end{array}$ & & $\begin{array}{c}0.16 \\
(0.54)\end{array}$ & \\
\hline$d e b t_{t-2}$ & $\begin{array}{c}0.91 \\
(3.27)\end{array}$ & $\begin{array}{c}0.72 \\
(3.13)\end{array}$ & $\begin{array}{c}0.31 \\
(0.78)\end{array}$ & \\
\hline$g d e b t_{t-2}$ & $\begin{array}{c}-0.12 \\
(-1.35)\end{array}$ & & $\begin{array}{c}-0.34 \\
(-1.66)\end{array}$ & \\
\hline$s_{t d e b t}$ & $\begin{array}{c}-0.00 \\
(-0.00)\end{array}$ & & $\begin{array}{c}0.76 \\
(1.61)\end{array}$ & $\begin{array}{c}0.78 \\
(1.89)\end{array}$ \\
\hline$r_{t-4}$ & $\begin{array}{c}0.53 \\
(3.58)\end{array}$ & $\begin{array}{c}0.42 \\
(3.05)\end{array}$ & $\begin{array}{c}1.17 \\
(3.82)\end{array}$ & $\begin{array}{c}1.11 \\
(3.80)\end{array}$ \\
\hline$d c e_{t-4}$ & $\begin{array}{c}0.01 \\
(0.07)\end{array}$ & & $\begin{array}{c}-0.22 \\
(-1.22)\end{array}$ & \\
\hline bis $_{t-4}$ & $\begin{array}{c}-0.01 \\
(-0.11)\end{array}$ & & $\begin{array}{c}0.34 \\
(1.20)\end{array}$ & \\
\hline bisdc ${ }_{t-4}$ & $\begin{array}{c}0.02 \\
(0.06)\end{array}$ & & $\begin{array}{c}0.85 \\
(1.46)\end{array}$ & $\begin{array}{c}0.99 \\
(2.05)\end{array}$ \\
\hline bkrat $_{t-4}$ & $\begin{array}{c}0.42 \\
(0.84)\end{array}$ & & $\begin{array}{c}-0.25 \\
(-0.19)\end{array}$ & \\
\hline
\end{tabular}

Note: t-statistics in parentheses.

26 For example, Bussière and Mulder (1999) and Eichengreen and Rose (1998).

27 Given the individual characteristic of crises observed in various countries, we also experimented with estimating separate regressions for individual countries. As in the pooled regressions, the real effective exchange rate and the debt indicators were the most potent. However, the number of observations in these regressions was necessarily much smaller than in the pooled regressions. 
Several indicators appear insignificant in Table 7 and in the country specific results. But we repeat this is only an illustrative exercise. With the short run of data available, we would not overrule the judgement of experienced colleagues who suggested the inclusion of the indicators in the vulnerability indices.

\section{Conclusion}

The trial exercise of constructing indices of financial market pressure, external vulnerability and banking system vulnerability has now been under way for over a year. Predicting the exact timing of a currency crisis is likely to be impossible as it depends on factors such as the credibility of the authorities in defending the exchange rate, on the force of financial contagion and on volatile market sentiment. Rather than generating spuriously exact predictions, the approach here aims to narrow the list of emerging economies to those experiencing incipient exchange market pressure or vulnerable to it. To this end, some relatively simple and transparent summary indices of pressure and vulnerability can be a helpful starting point.

Econometric results are uneven but suggest that the indicators selected and the approach used has some useful predictive power. However, the current framework was implemented after the Asian crises and it was easier to find a set of indicators to fit empirical facts. "Out of sample" forecasts have not yet been undertaken as the sample period was too short to draw firm conclusions and the next crisis has not yet arrived. With regard to the leading indicators, the results obtained are broadly consistent with the main findings of other studies on early-warning systems.

An improvement of the early-warning system could possibly be achieved by adding more economic indicators and, in some cases, by changing the thresholds. Incorporating contagion effects, the quality of banking supervision and political conditions may help prediction, but it is very difficult to capture such qualitative elements empirically. 
Table A1

First core table: Indicators of exchange market pressure (as at September 1998)

\begin{tabular}{|c|c|c|c|c|c|c|c|c|c|}
\hline & \multirow{3}{*}{$\begin{array}{l}1997 \\
\mathrm{Q}^{1}\end{array}$} & \multicolumn{4}{|c|}{1998} & \multicolumn{4}{|c|}{ Components in August: } \\
\hline & & \multirow[t]{2}{*}{$\mathrm{Q} 1{ }^{1}$} & \multirow[t]{2}{*}{$\mathrm{Q} 2^{1}$} & \multirow[t]{2}{*}{ July } & \multirow[t]{2}{*}{ August } & \multicolumn{2}{|c|}{$\begin{array}{c}\text { Percentage change in } \\
\text { the exchange rate }\end{array}$} & \multirow[t]{2}{*}{ Interest rates $^{3}$} & \multirow[t]{2}{*}{$\begin{array}{l}\text { Change in } \\
\text { reserves }\end{array}$} \\
\hline & & & & & & Three months & One year & & \\
\hline India & 2 & 2 & 3 & 4 & 3 & -5.5 & -16.0 & -2.9 & -1.8 \\
\hline China & 0 & 5 & 5 & 0 & 3 & 0.0 & 0.1 & 4.7 & -0.1 \\
\hline Hong Kong & 2 & 3 & 2 & 4 & 5 & 0.0 & -0.1 & 10.1 & -2.2 \\
\hline Taiwan & 7 & 6 & 4 & 5 & 5 & -3.5 & -17.2 & 5.0 & -0.7 \\
\hline Indonesia & 9 & 5 & 3 & 4 & 5 & -15.6 & -77.7 & -21.2 & 2.8 \\
\hline Korea & 8 & 7 & 1 & 4 & 4 & 6.4 & -31.7 & 12.1 & 6.0 \\
\hline Malaysia & 8 & 5 & 3 & 8 & 8 & -9.3 & -34.4 & 6.7 & -0.2 \\
\hline Philippines & 8 & 7 & 1 & 4 & 6 & -9.1 & -31.8 & 3.0 & -2.7 \\
\hline Singapore & 4 & 6 & 5 & 7 & 6 & -6.8 & -14.8 & 6.2 & -3.4 \\
\hline Thailand & 8 & 7 & 5 & 8 & 7 & -6.1 & -22.1 & 6.2 & 1.0 \\
\hline Argentina & 4 & 3 & 3 & 4 & 3 & 0.0 & 0.0 & 7.1 & 6.1 \\
\hline Brazil & 8 & 4 & 4 & 8 & 8 & -2.0 & -7.2 & 15.1 & -9.6 \\
\hline Chile & 3 & 9 & 6 & 8 & 9 & -3.8 & -12.1 & 10.9 & -10.0 \\
\hline Colombia & 7 & 7 & 3 & 4 & 6 & -0.3 & -18.4 & 9.7 & -1.9 \\
\hline Mexico & 5 & 3 & 3 & 6 & 7 & -8.4 & -16.9 & 12.3 & -0.9 \\
\hline Peru & 2 & 3 & 2 & 3 & 4 & -4.0 & -10.4 & 2.7 & 0.0 \\
\hline Venezuela & 0 & 4 & 3 & 3 & 8 & -6.0 & -13.3 & 4.3 & -11.8 \\
\hline Russia & 7 & 6 & 6 & 6 & 8 & -18.2 & -22.7 & 73.9 & -1.9 \\
\hline Czech Republic & 3 & 3 & 0 & 3 & 5 & 1.7 & 2.9 & 8.6 & 1.6 \\
\hline Hungary & 6 & 1 & 1 & 5 & 6 & -4.3 & -13.5 & 9.0 & -3.0 \\
\hline Poland & 5 & 1 & 2 & 3 & 5 & -3.8 & -5.6 & 16.6 & 7.6 \\
\hline Turkey & 4 & 5 & 3 & 8 & 8 & -8.0 & -40.3 & 19.2 & -7.6 \\
\hline Saudi Arabia & 5 & 4 & 3 & 5 & 5 & 0.0 & 0.0 & 9.3 & -3.8 \\
\hline South Africa & 6 & 6 & 6 & 9 & 9 & -19.4 & -25.9 & 8.6 & -4.7 \\
\hline
\end{tabular}

Note: The index of exchange market pressure is based on the data shown in italics on the right-hand side of the table: the higher the "score", the greater the pressure (maximum $=10$ ). Fuller details of the calculations are given in Annex B.

Average of period. ${ }^{2}$ Monthly average. ${ }^{3}$ Three-month interest rate (monthly average) less the annualised percentage change in consumer prices over the previous six months. ${ }^{4}$ Change over three months as a percentage of a 12 -month moving average of imports. 
Table A2

Second core table: Indicators of external vulnerability (as at September 1998)

\begin{tabular}{|c|c|c|c|c|c|c|c|c|c|c|}
\hline & \multirow[t]{3}{*}{$1996^{1}$} & \multirow[t]{3}{*}{$1997^{1}$} & \multicolumn{2}{|c|}{1998} & \multicolumn{6}{|c|}{ Components in the second quarter of 1998: } \\
\hline & & & \multirow[t]{2}{*}{$\mathrm{Q} 1{ }^{1}$} & \multirow[t]{2}{*}{$\mathrm{Q} 2{ }^{1}$} & \multirow{2}{*}{$\begin{array}{c}\text { Real effective } \\
\text { exchange } \\
\text { rate }\end{array}$} & \multirow{2}{*}{$\begin{array}{l}\text { Current } \\
\text { account } \\
\text { balance }\end{array}$} & \multirow[t]{2}{*}{$\begin{array}{l}\text { Export } \\
\text { growth }\end{array}$} & \multicolumn{2}{|c|}{$\begin{array}{l}\text { International bond and bank } \\
\text { debt as a \% of GDP }\end{array}$} & \multirow{2}{*}{$\begin{array}{l}\text { Short-term } \\
\text { debt as a \% } \\
\text { of reserves }\end{array}$} \\
\hline & & & & & & & & Level & $\begin{array}{l}\% \text { change } \\
\text { over } 2 \text { years }\end{array}$ & \\
\hline India & -1 & 0 & 2 & 2 & 0.9 & -1.8 & -16.6 & 6.7 & 20.6 & 28 \\
\hline China & 1 & -3 & 0 & -1 & 12.4 & 2.0 & -14.3 & 10.2 & -13.8 & 13 \\
\hline Hong Kong & 3 & 3 & 3 & 4 & 33.8 & -2.8 & -14.9 & .. & .. & .. \\
\hline Taiwan & -2 & -2 & -1 & 0 & -9.6 & 1.1 & -14.9 & 9.6 & 4.4 & 15 \\
\hline Indonesia & 5 & 6 & 6 & 4 & -55.4 & 2.7 & -19.6 & 42.2 & 61.4 & 75 \\
\hline Korea & 6 & 6 & 1 & 0 & -25.1 & 7.3 & -12.1 & 29.9 & 25.6 & 59 \\
\hline Malaysia & 3 & 6 & 4 & 3 & -18.2 & 0.2 & -24.1 & 36.5 & 20.0 & 27 \\
\hline Philippines & 3 & 5 & 3 & 3 & -6.0 & -1.6 & -4.9 & 28.3 & 55.6 & 64 \\
\hline Singapore & 0 & 0 & 0 & 0 & 4.4 & 12.4 & -26.8 & .. & .. & .. \\
\hline Thailand & 8 & 6 & 0 & 0 & -13.8 & 7.5 & -20.1 & 40.8 & -30.4 & 45 \\
\hline Argentina & 4 & 5 & 8 & 8 & 11.0 & -4.7 & -5.2 & 23.1 & 26.6 & 159 \\
\hline Brazil & 0 & 2 & 3 & 5 & 11.8 & -4.0 & -6.8 & 17.3 & 32.2 & 114 \\
\hline Chile & 2 & 5 & 7 & 7 & 17.6 & -7.3 & -17.2 & 30.9 & 36.1 & 49 \\
\hline Colombia & 3 & 5 & 5 & 7 & 24.5 & -5.3 & -16.3 & 21.1 & 55.8 & 70 \\
\hline Mexico & 5 & 4 & 3 & 3 & 4.8 & -3.1 & -13.6 & 26.0 & -2.2 & 82 \\
\hline Peru & 3 & 2 & 4 & 5 & 10.1 & -6.6 & -34.6 & 13.2 & 40.5 & 74 \\
\hline Venezuela & -5 & -2 & 5 & 5 & 53.8 & -2.7 & -31.9 & 29.6 & 53.0 & 41 \\
\hline Russia & 2 & 4 & 4 & 4 & 89.6 & -0.8 & -17.3 & 16.1 & -12.7 & 140 \\
\hline Czech Republic & 4 & 6 & 3 & 5 & 30.1 & -3.9 & -6.4 & 20.0 & 10.6 & 41 \\
\hline Hungary & 1 & 1 & 0 & 1 & 14.0 & -3.0 & 11.2 & 47.5 & -4.4 & 62 \\
\hline Poland & -1 & 1 & 3 & 4 & 33.7 & -4.7 & 0.0 & 9.0 & 39.3 & 25 \\
\hline Turkey & 1 & 0 & 0 & 1 & -1.8 & -2.2 & -8.0 & 24.3 & -15.4 & 101 \\
\hline Saudi Arabia & -3 & -1 & 3 & 3 & 6.7 & -3.2 & -37.7 & 15.5 & 68.7 & .. \\
\hline South Africa & 4 & 4 & 6 & 6 & -7.2 & -1.7 & -22.6 & 18.9 & 56.1 & 232 \\
\hline
\end{tabular}

Note: The index of external vulnerability is based on the data shown in italics on the right-hand side of the table: the higher the "score", the greater the vulnerability (maximum $=10)$.

${ }^{1}$ Average of period. ${ }^{2}$ As a percentage deviation from the 1990-98 average level. ${ }^{3}$ As a percentage of forecast GDP for the current year. ${ }^{4}$ Percentage growth of exports over past four quarters (in US dollars) minus average annual growth over the period 1990-98. ${ }^{5}$ Liabilities to BIS reporting banks plus international bonds outstanding as a percentage of GDP; GDP is converted into US dollars using smoothed exchange rates based on the World Bank Atlas method. ${ }^{6}$ Short-term liabilities (with a maturity of less than one year) to BIS reporting banks as a percentage of foreign exchange reserves. 
Table A3

Third core table: Indicators of banking system vulnerability (as at September 1998)

\begin{tabular}{|c|c|c|c|c|c|c|c|c|c|}
\hline & \multirow[t]{2}{*}{$1996^{1}$} & \multirow[t]{2}{*}{$1997^{1}$} & \multicolumn{2}{|c|}{1998} & \multicolumn{5}{|c|}{ Components in the second quarter of $1998:$} \\
\hline & & & Q1 ${ }^{1}$ & $\mathrm{Q} 2^{1}$ & $\begin{array}{c}\text { Domestic bank } \\
\text { credit to the private } \\
\text { sector }\end{array}$ & $\begin{array}{l}\text { Liabilities to } \\
\text { BIS reporting } \\
\text { banks }_{3}\end{array}$ & $\begin{array}{l}\text { Liabilities to BIS } \\
\text { reporting banks as a } \\
\% \text { of domestic credit }{ }^{4}\end{array}$ & Interest rate ${ }^{5}$ & $\begin{array}{l}\text { Average banking } \\
\text { rating }\end{array}$ \\
\hline India & 1 & 2 & 2 & 2 & 17 & 0.7 & 10 & 1 & .. \\
\hline China & 4 & 6 & 4 & 5 & 4 & 1.4 & 7 & 10 & .. \\
\hline Hong Kong & 0 & 1 & 0 & 1 & -1 & .. & .. & 2 & $\mathrm{~B}$ to $\mathrm{A} / \mathrm{B}$ \\
\hline Taiwan & 1 & 2 & 2 & 2 & -8 & 0.6 & 5 & 4 & $\mathrm{C}$ to $\mathrm{B} / \mathrm{C}$ \\
\hline Indonesia & 5 & 7 & 9 & 8 & 13 & 3.3 & 39 & -33 & $\mathrm{E}$ to $\mathrm{D} / \mathrm{E}$ \\
\hline Korea & 8 & 8 & 8 & 8 & 14 & -3.1 & 29 & 6 & $E$ to $D / E$ \\
\hline Malaysia & 6 & 7 & 8 & 4 & -2 & 2.0 & 27 & 2 & $\mathrm{D}$ to $\mathrm{C} / \mathrm{D}$ \\
\hline Philippines & 7 & 9 & 9 & 4 & -4 & 6.5 & 28 & 1 & $\mathrm{D}$ to $\mathrm{C} / \mathrm{D}$ \\
\hline Singapore & 0 & -1 & 3 & 2 & -3 & .. & .. & 8 & $\mathrm{~B}$ to $\mathrm{A} / \mathrm{B}$ \\
\hline Thailand & 8 & 8 & 8 & 6 & -9 & -17.1 & 39 & 12 & $\mathrm{E}$ to $\mathrm{D} / \mathrm{E}$ \\
\hline Argentina & 4 & 5 & 4 & 4 & -2 & 3.7 & 24 & 5 & $\mathrm{D}$ to $\mathrm{C} / \mathrm{D}$ \\
\hline Brazil & 4 & 5 & 7 & 6 & 5 & 3.9 & 30 & 18 & $\mathrm{D}$ to $\mathrm{C} / \mathrm{D}$ \\
\hline Chile & 5 & 4 & 4 & 5 & 4 & 9.0 & 9 & 13 & $\mathrm{~B}$ to $\mathrm{A} / \mathrm{B}$ \\
\hline Colombia & 6 & 5 & 7 & 6 & 37 & 5.4 & 21 & 1 & $\mathrm{E}$ to $\mathrm{D} / \mathrm{E}$ \\
\hline Mexico & 4 & 5 & 4 & 4 & -3 & -0.2 & 25 & 2 & $\mathrm{E}$ to $\mathrm{D} / \mathrm{E}$ \\
\hline Peru & 5 & 6 & 6 & 6 & 13 & 5.2 & 32 & 3 & .. \\
\hline Venezuela & 5 & 7 & 7 & 5 & 41 & 2.3 & 29 & -5 & $\mathrm{D}$ to $\mathrm{C} / \mathrm{D}$ \\
\hline Russia & 5 & 5 & 8 & 8 & 13 & 4.2 & 99 & 29 & $\mathrm{E}$ to $\mathrm{D} / \mathrm{E}$ \\
\hline Czech Republic & 5 & 5 & 3 & 4 & -9 & 3.4 & 16 & 3 & $\mathrm{D}$ to $\mathrm{C} / \mathrm{D}$ \\
\hline Hungary & 4 & 6 & 7 & 7 & 14 & 11.3 & 67 & -2 & $\mathrm{D}$ to $\mathrm{C} / \mathrm{D}$ \\
\hline Poland & 3 & 5 & 6 & 6 & 18 & 2.4 & 12 & 6 & $\mathrm{D}$ to $\mathrm{C} / \mathrm{D}$ \\
\hline Turkey & 5 & 6 & 6 & 5 & -11 & 8.2 & 35 & 0 & $\mathrm{D}$ to $\mathrm{C} / \mathrm{D}$ \\
\hline Saudi Arabia & 2 & 2 & 4 & 4 & 27 & .. & .. & 5 & $\mathrm{~B}$ to $\mathrm{A} / \mathrm{B}$ \\
\hline South Africa & 3 & 4 & 5 & 5 & 22 & 4.8 & 12 & 8 & $\mathrm{~B}$ to $\mathrm{A} / \mathrm{B}$ \\
\hline
\end{tabular}




\section{Annex B: Indicator definitions and the scoring system}

\section{Exchange market pressure index}

The indicators used are:
$x r m=$ Percentage appreciation of the domestic currency against the US dollar over three months (against the euro for central Europe)
$x r a=$ Percentage appreciation of the domestic currency against the US dollar over one year (against the euro for central Europe)
$r=$ Three-month interest rate less the annualised percentage change in consumer prices over the previous six months
res $=$ Change in reserves over three months as a percentage of the 12-month moving average of imports

The bands and scores used were:

\begin{tabular}{|c|c|c|c|c|c|c|}
\hline \multicolumn{2}{|c|}{ Indicator } & -2 & -1 & 0 & 1 & 2 \\
\cline { 1 - 6 } Code & Weight & & & & & \\
\hline$x r m$ & $W_{1}$ & $10<\mathrm{x}$ & $2<\mathrm{x} \leq 10$ & $2 \geq \mathrm{x}>-3$ & $-3 \geq \mathrm{x}>-8$ & $\mathrm{x} \leq-8$ \\
\hline$x r a$ & $W_{2}$ & $20<\mathrm{x}$ & $5<\mathrm{x} \leq 20$ & $5 \geq \mathrm{x}>-5$ & $-5 \geq \mathrm{x}>-20$ & $\mathrm{x} \leq-20$ \\
\hline$r$ & $W_{3}$ & & & $\mathrm{x} \leq 2$ & $2<\mathrm{x} \leq 4$ & $\mathrm{x}>4$ \\
\cline { 1 - 6 } res & $W_{4}$ & $8<\mathrm{x}$ & $4<\mathrm{x}<8$ & $4 \geq \mathrm{x}>-4$ & $-4>\mathrm{x} \geq-8$ & $\mathrm{x}<-8$ \\
\hline
\end{tabular}

The shaded box indicates no "points gained" for negative real interest rates.

The weighting system follows the algorithm:

- $\mathrm{W}_{1}=\mathrm{W}_{2}=\mathrm{W}_{3}=\mathrm{W}_{4}=1.25$

- If the interest rate variable $\geq 8$, then $\mathrm{W}_{3}=2.5 ; \mathrm{W}_{1}=\mathrm{W}_{2}=0.625 ;$ and $\mathrm{W}_{4}=1.25$. $^{28}$

The reason for doing this is that a country with such high real interest rates is likely to be in trouble even if the exchange rate is fixed.

28 For $4<\mathrm{r}<8, \mathrm{~W}_{3}$ increases proportionally, and the other weights are correspondingly reduced, so that the sum of the weights remains constant. 


\section{External vulnerability index}

The indicators used are:

\begin{tabular}{|c|c|c|}
\hline reer & $=$ & $\begin{array}{l}\text { Real effective exchange rate, as a percentage deviation from the average level } \\
\text { over 1990-98 }\end{array}$ \\
\hline $\operatorname{cgdp}$ & $=$ & Current account balance as a percentage of GDP \\
\hline$g x$ & $=$ & $\begin{array}{l}\text { Growth of exports over past four quarters (US dollar value) minus average annual } \\
\text { growth over 1990-98 (in percentage) }\end{array}$ \\
\hline$d e b t$ & $=$ & $\begin{array}{l}\text { "Quick" external debt as a \% of GDP. GDP is converted into US dollars using an } \\
\text { exchange rate based on the World Bank Atlas method }{ }^{29}\end{array}$ \\
\hline gdebt & $=$ & Growth in the "debt" indicator over the past eight quarters (in percentage) \\
\hline stdebt & $=$ & Short-term debt as a percentage of foreign exchange reserves \\
\hline & & $\begin{array}{l}\text { Short-term debt defined as consolidated cross-border claims of all BIS reporting } \\
\text { banks on countries outside the reporting area with a maturity up to and including } \\
\text { one year plus international debt securities outstanding with a maturity up to one } \\
\text { year. }\end{array}$ \\
\hline
\end{tabular}

The bands and scores used were:

\begin{tabular}{|c|c|c|c|c|c|c|}
\hline \multicolumn{2}{|c|}{ Indicator } & \multirow{2}{*}{-2} & -1 & 0 & 1 & 2 \\
\cline { 1 - 6 } Code & Weight & & & & & \\
\cline { 1 - 6 } reer & $W_{1}$ & $-20 \geq \mathrm{x}$ & $-20<\mathrm{x} \leq-10$ & $-10<\mathrm{x} \leq 10$ & $10<\mathrm{x} \leq 20$ & $\mathrm{x}>20$ \\
\hline$c g d p$ & $W_{2}$ & $\mathrm{x}>4$ & $2<\mathrm{x} \leq 4$ & $-2<\mathrm{x} \leq 2$ & $-4<\mathrm{x} \leq-2$ & $-4 \geq \mathrm{x}$ \\
\hline$g x$ & $W_{3}$ & $\mathrm{x}>10$ & $10 \leq \mathrm{x}<5$ & $0<\mathrm{x} \leq 5$ & $-5<\mathrm{x} \leq 0$ & $-5 \geq \mathrm{x}$ \\
\hline debt & $W_{4}$ & & $\mathrm{x} \leq 20$ & $20<\mathrm{x} \leq 30$ & $30<\mathrm{x} \leq 40$ & $\mathrm{x}>40$ \\
\hline gdebt & $W_{5}$ & $-10 \geq \mathrm{x}$ & $-10<\mathrm{x} \leq 0$ & $0<\mathrm{x} \leq 10$ & $10<\mathrm{x} \leq 15$ & $\mathrm{x}>15$ \\
\hline stdebt & $W_{6}$ & & $\mathrm{x} \leq 50$ & $50<\mathrm{x} \leq 100$ & $100<\mathrm{x} \leq 150$ & $\mathrm{x}>150$ \\
\hline
\end{tabular}

The weighting system follows the algorithm:

- $\mathrm{W}_{1}=\mathrm{W}_{2}=\mathrm{W}_{3}=\mathrm{W}_{4}=\mathrm{W}_{5}=\mathrm{W}_{6}=5 / 6$

- If stdebt $>200 \%$ then $\mathrm{W}_{6}=10 / 6 ; \mathrm{W}_{1}=\mathrm{W}_{2}=\mathrm{W}_{3}=\mathrm{W}_{4}=\mathrm{W}_{5}=2 / 3$

The reason for doing this is that countries are likely to be very vulnerable when short-term debt is very high even when the values of other indicators are low.

29

The Atlas conversion factor is the average of a country's exchange rate for the current year and its exchange rate for the two preceding years, after adjustment for differences in rates of inflation between the country in question and the United States. 


\section{Banking system vulnerability index}

The indicators used are:

\begin{tabular}{|c|c|c|}
\hline dce & $=$ & $\begin{array}{l}\text { Increase in domestic credit (to the private sector)/GDP ratio over four quarters, } \\
\text { (in percentage) }\end{array}$ \\
\hline bis & $=$ & $\begin{array}{l}\text { Increase in liabilities to BIS reporting banks over eight quarters as a percentage } \\
\text { to GDP. GDP is converted into US dollars using an exchange rate based on the } \\
\text { World Bank Atlas approach (see footnote 29) }\end{array}$ \\
\hline$b i s d c$ & $=$ & $\begin{array}{l}\text { Liabilities to BIS reporting banks (vis-à-vis the banking sector) as a percentage } \\
\text { of domestic credit to the private sector }\end{array}$ \\
\hline$r$ & $=$ & $\begin{array}{l}\text { Three-month interest rate less the annualised percentage change in consumer } \\
\text { prices over the previous } 6 \text { months }\end{array}$ \\
\hline bkrat & $=$ & $\begin{array}{l}\text { Average credit rating of banks. Source: Fitch IBCA, average of individual } \\
\text { ratings }\end{array}$ \\
\hline
\end{tabular}

The bands and scores used were:

\begin{tabular}{|c|c|c|c|c|c|c|}
\hline \multicolumn{2}{|c|}{ Indicator } & \multirow{2}{*}{-2} & \multirow{2}{*}{-1} & \multirow{2}{*}{0} & \multirow{2}{*}{1} & \multirow{2}{*}{2} \\
\hline Code & Weight & & & & & \\
\hline dce & $W_{l}$ & & & $x \leq 5$ & $5<x \leq 10$ & $x>10$ \\
\hline bis & $W_{2}$ & & & $x \leq 5$ & $5<x \leq 8$ & $x>8$ \\
\hline bisdc & $W_{3}$ & & & $\mathrm{x} \leq 10$ & $10<x \leq 25$ & $x>25$ \\
\hline$r$ & $W_{4}$ & & & $-8 \leq x<2$ & $2<x \leq 4$ & $\begin{array}{c}x>4 \text { or } \\
x<-8\end{array}$ \\
\hline bkrat & $W_{5}$ & A & $\mathrm{B}$ to $\mathrm{A} / \mathrm{B}$ & $\mathrm{C}$ to $\mathrm{B} / \mathrm{C}$ & $\mathrm{D}$ to $\mathrm{C} / \mathrm{D}$ & $\mathrm{E}$ to $\mathrm{D} / \mathrm{E}$ \\
\hline
\end{tabular}

The weighting system follows the algorithm:

- $\mathrm{W}_{1}=\mathrm{W}_{2}=\mathrm{W}_{3}=\mathrm{W}_{4}=\mathrm{W}_{5}=1$ 
Annex C: Further econometric results

Table C1: Correlations between indicators (as a test for redundancy)

I. Exchange market pressures

\begin{tabular}{lccc}
\hline & $\boldsymbol{x r m}$ & $\boldsymbol{x r a}$ & $\boldsymbol{r}$ \\
\hline xra & 0.73 & & \\
$r$ & 0.01 & 0.01 & \\
res & 0.01 & -0.07 & 0.01 \\
\hline
\end{tabular}

II. External vulnerability

\begin{tabular}{lccccc}
\hline & reer & cgdp & gx & debt & gdebt \\
\hline$c g d p$ & 0.17 & & & & \\
$g x$ & -0.12 & 0.01 & & & \\
debt & -0.03 & 0.32 & 0.01 & & \\
gdebt & -0.05 & 0.02 & -0.04 & -0.19 & \\
stdebt & -0.04 & -0.06 & 0.05 & -0.09 & -0.01 \\
\hline
\end{tabular}

III. Banking sector vulnerability

\begin{tabular}{lcrrr}
\hline & dce & bis & bisdc & $\boldsymbol{r}$ \\
\hline bis & 0.08 & & & \\
bisdc & -0.10 & 0.18 & & \\
$r$ & 0.03 & -0.02 & -0.07 & \\
bkrat & -0.06 & 0.01 & 0.08 & 0.06 \\
\hline
\end{tabular}

For definitions of indicators see Annex B. 
Table C2: Distribution of the indicators across the bands

I. Exchange market pressure (in \%)

\begin{tabular}{lccccc}
\hline & $\mathbf{- 2}$ & $\mathbf{- 1}$ & $\mathbf{0}$ & $\mathbf{1}$ & $\mathbf{2}$ \\
\hline$x r m$ & 2 & 9 & 54 & 19 & 16 \\
$x r a$ & 1 & 7 & 37 & 33 & 22 \\
$r$ & & 38 & 13 & 49 \\
$r e s$ & 36 & 13 & 29 & 7 & 15 \\
\hline
\end{tabular}

II. External vulnerability (in \%)

\begin{tabular}{lccccc}
\hline & $\mathbf{- 2}$ & $\mathbf{- 1}$ & $\mathbf{0}$ & $\mathbf{1}$ & $\mathbf{2}$ \\
\hline reer & 5 & 12 & 64 & 12 & 7 \\
cgdp & 15 & 8 & 31 & 16 & 30 \\
$g x$ & 18 & 12 & 12 & 8 & 40 \\
debt & & 44 & 40 & 8 & 8 \\
gdebt & 10 & 34 & 4 & 32 \\
stdebt & 20 & 51 & 9 & 19 \\
\hline
\end{tabular}

III. Banking sector vulnerability (in \%)

\begin{tabular}{|c|c|c|c|c|c|}
\hline & -2 & -1 & 0 & 1 & 2 \\
\hline$d c e$ & & & 49 & 24 & 27 \\
\hline bis & & & 85 & 7 & 8 \\
\hline bisdc & & & 43 & 31 & 26 \\
\hline$r$ & & & 27 & 12 & 61 \\
\hline bkrat & 0 & 6 & 26 & 47 & 20 \\
\hline
\end{tabular}

For definitions of indicators see Annex B. 


\section{References}

Aziz, J, F Caramazza and R. Salgado (2000): "Currency crises: in search of common elements". IMF working paper, 00/67, March. www.imf.org

Berg, A and C Pattillo (1999): “Are currency crises predictable? A test”. IMF Staff Papers Vol 46, No 2, June, pp 107-138. www.imf.org

Berg, A, Borensztein, G-M Milesi-Ferretti and C Pattillo: (2000) "Anticipating balance of payments crises - the role of early warning systems". IMF occasional paper, No 186, January.

Burkart, O and V Couderc (2000): "Leading indicators of currency crises in emerging economies". Mimeo, Banque de France.

Bussière, M and C Mulder (1999): "External vulnerability in emerging market economies: how high liquidity can offset weak fundamentals and the effects of contagion”. IMF working paper, 99/88, July. www.imf.org

Carramazza, F, L Ricci and R Salgado (2000): “Trade and financial contagion in currency crises". IMF working paper, 00/55, March. evww.imf.org

Committee on the Global Financial System (1998a): "Enhancing transparency regarding the authorities' foreign currency liquidity position". Paper 9, September. www.bis.org

Committee on the Global Financial System (1998b): "Review of the disclosure template regarding the authorities' foreign currency liquidity position". Paper 9a, September. www.bis.org

Corsetti, G, P Pesenti and N Roubini (1998): "Paper tigers? A model of the Asian crisis". National Bureau of Economic Research working paper, No 6783, November.

Demirgüç-Kunt, A and E Detragiache (1998): "The Determinants of Banking Crises in Developing and Developed Countries". IMF Staff Papers, Vol 45, No 1, March, pp 81-109. www.imf.org.

Deutsche Bundesbank (1999): "The role of economic fundamentals in the emergence of currency crises in emerging markets". Deutsche Bundesbank Monthly Report, April, pp 15-27.

Economist (1998): “The perils of prediction”. The Economist, 1 August.

Edison, H (2000): "Do indicators of financial crises work? An evaluation of an early warning system". Board of Governors of the Federal Reserve System International Finance Discussion Paper, No 675, July.

Eichengreen, B and A Rose (1998): "Staying afloat when the wind shifts: external factors and emerging-market banking crises". NBER working paper, No 6370, January. 
Eichengreen, B, A Rose and C Wyplosz (1995): "Exchange market mayhem: the antecedents and aftermath of speculative attacks". Economic Policy, Vol October, pp 249-312.

Eichengreen, B, A Rose and C Wyplosz (1996): “Contagious currency crises". NBER working paper, No 5681 .

Esquivel, G and F Larrain (1998): "Explaining currency crises". Harvard Institute for International Development, June.

Evans, O, A Leone, M Gillard and R Hilbers (2000): "Macroprudential indicators of financial system soundness". IMF occasional paper, No 192, April.

Flood, R and N Marion (1998): "Perspectives on the recent currency crisis literature". NBER working paper, No 6830.

Frankel, J and A Rose (1996): "Currency crashes in emerging markets: an empirical treatment". Journal of International Economics, November, pp 351-366.

Fratzscher, M (1998): "Why are currency crises contagious? A comparison of the Latin American crisis of 1994-95 and the Asian crisis of 1997-98". Weltwirtschaftliches Archiv, Vol 134, No 4, pp 664-691.

Furman, J and J Stiglitz (1998): "Economic crises: evidence and insights from east Asia". Brookings Papers on Economic Activity, No 98:2, pp 1-114.

Glick, R and R Moreno (1999): "Money and credit, competitiveness, and currency crises in Asia and Latin America". Centre for Pacific Basin Monetary \& Economic Studies working paper PB99-01, Federal Reserve Bank of San Francisco.

Glick, R and M Hutchison (2000): "Banking and currency crises: how common are twins?" Hong Kong Institute for Monetary Research working paper, No 2000/1. www.hkimr.org Also appeared as Centre for Pacific Basin Monetary \& Economic Studies working paper PB99-07, Federal Reserve Bank of San Francisco.

Goldstein, M (1998): "Early warning indicators and the Asian financial crisis”. Unpublished paper.

Goldstein, M, G Kaminsky and C Reinhart (2000): Assessing Financial Vulnerability: an Early Warning System for Emerging Markets. Institute for International Economics, Washington DC, June.

Goldstein, M and J Hawkins (1998): “The origin of the Asian financial turmoil". Reserve Bank of Australia Research discussion paper, No 9805, May.

González-Hermosillo, B (1999): "Developing indicators to provide early warnings of banking crises". Finance and Development, Vol 36, No 2, June. 
Haque, N, M Nelson and D Mathieson (1998): "The relative importance of political and economic variables in creditworthiness ratings". IMF working paper, No 98/46, April. www.imf.org

Hardy, D and C Pazarbaşioğlu (1998): "Leading Indicators of Banking Crises - Was Asia Different?" IMF working paper, No 98/91, August. www.imf.org

Hawkins, J (1999): “Economic and financial monitoring” Australian Economic Indicators, January, pp $3-10$.

Hilbers, P, M Moretti and R Krueger (1999): "Seminar discusses ways to assess soundness of financial system to improve surveillance". IMF Survey 27, September, pp 296-7. www.imf.org

Honohan, P (1997): "Banking system failures in developing and transition countries: diagnosis and prediction”. BIS working paper, No 39, January. www.bis.org.

International Monetary Fund (1998a): International Capital Markets, September.

International Monetary Fund (1998b): "Chapter IV: Financial crises: characteristics and indicators of vulnerability". World Economic Outlook, May.

International Monetary Fund (1999a): International Capital Markets, September. www.imf.org

International Monetary Fund (1999b): “Chapter III: International financial contagion”. World Economic Outlook, May. www.imf.org

International Monetary Fund (2000): "Debt- and reserve-related indicators of external vulnerability", May. www.imf.org

Kamin, S and O Babson (1999): "The contributions of domestic and external factors to Latin American devaluation crisis: an early warning systems approach”. US Federal Reserve System International Finance Discussion Paper, No 645, September.

Kaminsky, G (1999): "Currency and banking crises: the early warnings of distress". IMF working paper, No 99/178, December. www.imf.org

Kaminsky, G, S Lizondo and C Reinhart (1998): "Leading indicators of currency crises". IMF Staff Papers, Vol 45, No 1, March, pp 1-48. www.imf.org

Kaminsky, G and C Reinhart (1999): "The twin crises: the causes of banking and balance-of-payment problems". American Economic Review, Vol 89, No 3, June, pp 473-500.

Kruger, M, P Osakwe and J Page (1998): "Fundamentals, contagion and currency crises: an empirical analysis". Bank of Canada working paper, No 98-10, July.

Krugman, P (1979): “A model of balance-of-payment crises”. Journal of Money, Credit and Banking, Vol 11, August, pp 311-25. 
Kumar, M, U Moorthy and W Perraudin (1998): "Determinants of emerging market currency crises and contagion effects". Paper presented to CEPR/World Bank conference "Financial crises: contagion and market volatility", London, 8-9 May.

Madsen, I (1998): "Country risk and leading indicators of financial crisis in emerging markets: a practical survey”. Unpublished paper.

Milesi-Ferritti, G and A Razin (1998): "Current account reversals and currency crises: empirical regularities". IMF working paper, No 98/99, June. www.imf.org

Persaud, A (1998): "Event risk indicator handbook". JP Morgan, London, 29 January.

Radelet, S and J. Sachs (1998): "The east Asian financial crisis: diagnosis, remedies, prospects". Brookings Papers on Economic Activity, pp 1-90.

Rossi, M (1999): "Financial fragility and economic performance in developing economies: do capital controls, prudential regulation and supervision matter?" IMF working paper, No 99/66, May. (www.imf.org

Roubini, N (1999): "What caused Asia's economic and currency crisis and its global contagion?" http://www.stern.nyu.edu/ NRoubini/Asia/AsiaHomepage.html

Sachs, J, A Tornell and A Velasco (1996): "Financial crises in emerging markets: the lessons from 1995". Brookings Papers on Economic Activity, 1996:1, pp 1-90.

Schnatz, B (1998): "Macroeconomic determinants of currency turbulences in emerging markets". Deutsche Bundesbank discussion paper, No 3/98.

Tornell, A (1999): "Common fundamentals in the Tequila and Asian crises"

Van Rijckeghem, C and B Weder (1999): “Sources of contagion: finance or trade?" IMF working paper, No 99/147, October. www.imf.org

Vlaar, P J G (2000): "Early warning systems for currency crises". BIS conference papers, Vol 8. March, pp 253-274. Also available as De Nederlandsche Bank reprint. No 671.

Working Group on Transparency and Accountability (1998): Report to G22 ("Willard" Group). October, BIS, (www.bis.org). 




\section{Recent BIS Working Papers}

No Title Author

75

August 1999

76

October 1999

77

October 1999

78

October 1999

79

November 1999

80

November 1999

81

November 1999

82

November 1999

83

January 2000

84

January 2000

85

January 2000

86

March 2000

87

May 2000

88

June 2000

89

August 2000

90

September 2000
A note on the Gordon growth model with nonstationary dividend growth

The price of risk at year-end: evidence from interbank lending

Perceived central bank intervention and market expectations: an empirical study of the yen/dollar exchange rate, 1993-96

Banking and commerce: a liquidity approach

Pass-through of exchange rates and import prices to domestic inflation in some industrialised economies

A note on alternative measures of real bond rates

Interbank interest rates and the risk premium

Sacrifice ratios and the conduct of monetary policy in conditions of low inflation

Switching from single to multiple bank lending relationships: determinants and implications

What have we learned from recent financial crises and policy responses?

A defence of the expectations theory as a model of US long-term interest rates

Information, liquidity and risk in the international interbank market: implicit guarantees and private credit market failure

Monetary policy in an estimated optimisation-based model with sticky prices and wages

Evidence on the response of US banks to changes in capital requirements

Forecast-based monetary policy

Bank capital regulation in contemporary banking theory: a review of the literature
Henri Pagès

Craig H Furfine

Gabriele Galati and

William Melick

Joseph G Haubrich and João A C Santos

Jonathan McCarthy

Palle S Andersen

Henri Pagès

Palle S Andersen and William L Wascher

Luísa A Farinha and João A C Santos

William R White

Gregory D Sutton

Henri Bernard and

Joseph Bisignano

Jeffery D Amato and Thomas Laubach

Craig Furfine

Jeffery D Amato and Thomas Laubach

João A C Santos 


ISSN 1020-0959 